\title{
Diazapyrenes: interaction with nucleic acids and biological activity
}

\author{
Andrey M. Zhirov ${ }^{1}$, Dmitry A. Kovalev ${ }^{1}$, Diana V. Ulshina ${ }^{1}$, \\ Sergey V. Pisarenko ${ }^{1}$, Oleg P. Demidov ${ }^{2}$, Ivan V. Borovlev ${ }^{2}$ \\ ${ }^{1}$ Stavropol Research Anti-Plague Institute, \\ 13-15 Sovetskaya St., Stavropol 355035, Russia; email: stavnipchi@mail.ru \\ ${ }^{2}$ North Caucasus Federal University, \\ la Pushkina St., Stavropol 355017,Russia; email: k-biochem-gcs@stavsu.ru
}

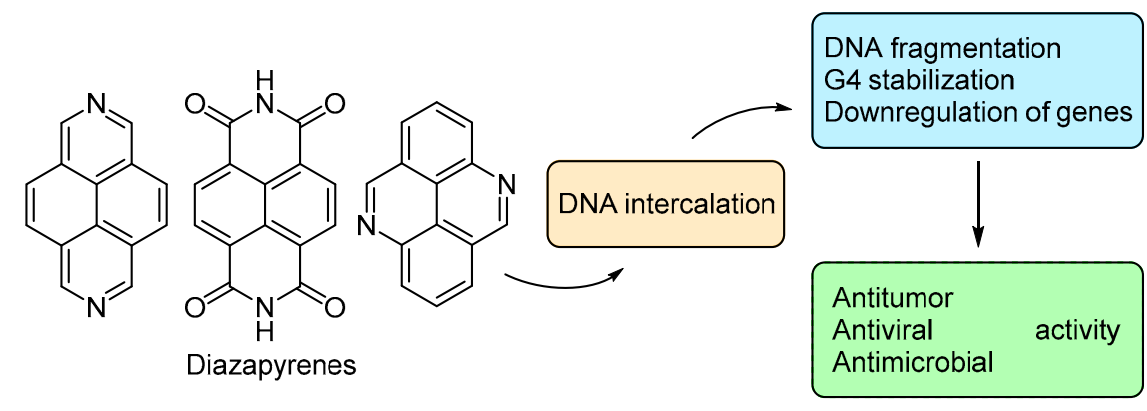

The review summarizes data on the practical aspects of the interaction of nucleic acids with diazapyrene derivatives. The information on biological activity is given and the probable mechanisms underlying the action of diazapyrenes are analyzed. It contains 119 references.

Keywords: diazapyrene, DNA, naphthalenediimide, RNA, biological activity, intercalation, G-quadruplex.

DNA is the pharmacological target for many drugs or compounds currently undergoing clinical trials. ${ }^{1}$ Developing new drugs and improving the effects of existing drugs is a complex task that goes beyond improving the specificity of a drug with respect to its biological target. Since in many cases only a small fraction of the administered drug compound reaches the pharmacological target, it is necessary to develop strategies for increasing the accumulation of the drug near cellular DNA. The drug delivery strategy should be aimed at increasing circulation time, enhancing tissue-specific accumulation, increasing the efficiency of cellular and nuclear uptake in addition to high specificity and affinity to DNA. The complexity of biological systems makes it difficult to simultaneously incorporate all of these factors into a single drug development algorithm. However, focusing on specificity is relatively simple because the structure of DNA is well known. ${ }^{2}$

Currently, there are many strategies of exploiting the known DNA structure for specific binding of drug compounds. One approach is to use small molecules that can recognize nucleic acids and bind to specific areas of DNA, major or minor grooves, or integrate between DNA bases arranged in specific nucleotide sequences.

One of the well-studied DNA targets of drugs is the G-quadruplexes (G4). ${ }^{3}$ G4 are secondary nucleic acid structures that can form in single-stranded guanine-rich sequences under physiological conditions. ${ }^{4}$ Four guanines are paired via hydrogen bonds to form G-quadruplexes. These structures are further stabilized in the presence of metal ions such as potassium ions. Studies of their stability showed that these noncanonical secondary DNA structures are capable of destabilizing the double helix, since many G4 structures are thermodynamically more stable than double-stranded DNA (dsDNA), and their denaturation rate is significantly lower. ${ }^{5}$

G4 sequences in eukaryotes play key regulatory functions, including transcriptional regulation of promoters ${ }^{5 b}$ and gene enhancers, ${ }^{5 b, 6}$ translation, ${ }^{5 b, 6,7}$ epigenetic regulation of chromatin $^{8}$ and DNA recombination. ${ }^{5 b, 8}$ 
In viruses, G4 are involved in key stages of the life cycle. ${ }^{9}$ The presence of functionally significant G4 in HIV is known, ${ }^{10}$ binding to which determines the antiviral effect of certain drugs. ${ }^{10, \mathrm{~b}, 11} \mathrm{G} 4$ were also found in the genomes of herpes virus, ${ }^{12}$ SARS coronavirus and human papillomavirus, ${ }^{13}$ Zika, Ebola, and hepatitis C viruses. ${ }^{14}$ In prokaryotes, G4 sequences were described in $E$. coli, ${ }^{6,15}$ D. radiodurans, ${ }^{16}$ Xanthomonas and Nostoc sp., ${ }^{17}$ as well as in the genes of $E$. coli, $C$. difficile, and Bacteroides sp., encoding helicases Pif1 and RecQ. ${ }^{18}$ Bacterial G4 are involved in antigenic variability of the protein pilin of the cell wall of Neisseria gonorrhoeae. $^{19}$

The mechanism of action of small molecules on DNA is based on covalent (e.g., cisplatin and bis- $\beta$-chloroethylamine derivatives) $)^{20}$ or noncovalent binding with the formation of hydrogen bonds, electrostatic, hydrophobic, and/or $\pi-\pi$ interactions. Noncovalent binders are divided into two types: compounds that bind to minor grooves (distamycin, netropsin, and Hoechst 33258), and intercalators (doxorubicin, acridine orange, etc.). ${ }^{21}$ Intercalators are molecules containing a flat fragment, usually consisting of several condensed rings, which interacts with dsDNA by inserting a flat fragment between adjacent base pairs of the double helix, while hydrophobic interactions and $\pi$-stacking stabilize the formed complex. ${ }^{22}$

It has been shown by many studies that intercalating compounds with antibacterial and antitumor activity are inhibitors of the enzymes topoisomerase $\mathrm{I},{ }^{23}$ topoisomerase $\mathrm{II}^{24}$ topoisomerase IV, and DNA gyrase. ${ }^{25}$ These enzymes are able to "relax" supercoiled DNA molecules by introducing single- or double-stranded breaks with subsequent recovery. Intercalation at the site of the interaction of DNA and topoisomerase leads to an increase in the distance between adjacent pairs of nucleotides and does not allow the enzyme to perform the final operation of suturing the cut ends, ${ }^{26}$ and the accumulation of breaks in the DNA chain, especially double ones, in turn triggers the process of apoptosis in the cell. Since replication processes are ongoing in tumor tissues, these cells are the most vulnerable to the action of topoisomerase inhibitors. ${ }^{27}$

Attention to azapyrenes is associated both with theoretical aspects and with the results of practical application. Polyazapyrenes are actively used to create molecular devices, ${ }^{28}$ redox sensors, ${ }^{29}$ compounds with a topological bond, ${ }^{30}$ host-guest molecules, ${ }^{31}$ and macrocomplexes with transition metal cations. ${ }^{32}$ An increase in interest in such structures is associated, among other things, with an increase in the number of methods for the synthesis of aza- and polyazapyrenes. ${ }^{33}$ In addition, triazapyrene derivatives, representatives of the aaptamine alkaloids family, were isolated from sea sponges of the South China Sea. ${ }^{34}$ Aaptamines exhibit a wide range of biological activity: antifungal, antibacterial, antitumor, antiviral, including antiHIV. ${ }^{35}$ This review presents data on the formation of complexes, including intercalation complexes, of diazapyrenes with nucleic acids and analyzes the biological activity of diazapyrenes mainly in the light of interaction with DNA.

\section{FEATURES OF THE INTERACTION OF DIAZAPYRENES WITH NUCLEIC ACIDS}

The interaction of 2,7-diazapyrenes and their quaternary salts with DNA was investigated by Becker et al. 2,7-Diazapyrene (1), $N$-methyl-2,7-diazapyrenium cation (2) and $N, N^{\prime}$-dimethyl-2,7-diazapyrenium dication (3) bind to dsDNA by intercalation with an approximately perpendicular orientation to the axis of the DNA helix. The thermodynamic parameters of the binding of 2,7-diazapyrenes to DNA are significantly different. Binding of 2,7-diazapyrene (1) proceeds with a negative change in enthalpy $\Delta H$ and a negative change in entropy $\Delta S$, while the binding of $N, N^{\prime}$-dimethyl2,7-diazapyrenium dication (3) is entropically favorable, but enthalpically disadvantageous. $N$-Methyl-2,7-diazapyrenium cation (2) occupies an intermediate position ${ }^{36}$ (Table 1).

When complexes of 2,7-diazapyrenium dication $\mathbf{3}$ (Table 1) and bis(2,7-diazapyrenium) dication 4 (Fig. 1) with supercoiled DNA are irradiated with visible light $(\lambda>395 \mathrm{~nm})$, breaks in the polynucleotide chain are observed. Intercalation of $N, N^{\prime}$-dimethyl-2,7-diazapyrenium dication (3) in this case leads to single breaks in the chain with the formation of damaged ring and linear DNA. Irradiation of bidentate complexes leads to a total cleavage of DNA with the formation of small fragments due to multiple cuts of both chains. ${ }^{37}$

By combining the DNA oligonucleotide and the 2,7-diazapyrenium fragment in one molecule, selective DNA cleavage was achieved. ${ }^{38}$ As a result, it was found that the DNA chain is cleaved at a distance of 2-3 nucleotides from the point of addition of the 2,7-diazapyrenium ring, mainly in $G$ and $G G$ units. ${ }^{39}$ In addition, functionalized oligonucleotides form a more

Table 1. Thermodynamic parameters of complexes of 2,7-diazapyrene (1) and its cations $\mathbf{2}, \mathbf{3}$ with DNA

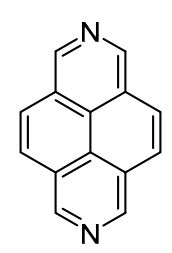

1

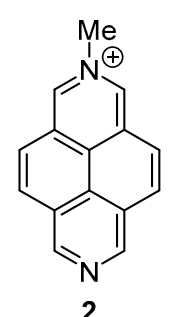

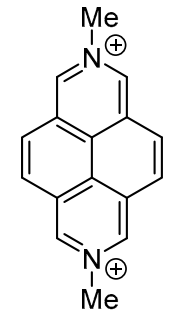

3

\begin{tabular}{lccc}
\hline \multicolumn{1}{r}{ Parameter* } & \multicolumn{3}{c}{ Compound/cation } \\
\cline { 2 - 4 } & $\mathbf{1}$ & $\mathbf{2}$ & $\mathbf{3}$ \\
\hline$\Delta H, \mathrm{kcal} \cdot \mathrm{mol}^{-1}$ & -9 & 3 & 5.2 \\
$\Delta S, \mathrm{cal} \cdot \mathrm{mol}^{-1}$ & -7 & 12 & 43 \\
$\Delta G, \mathrm{kcal} \cdot \mathrm{mol}^{-1}$ & -6.9 & -7.4 & 7.1 \\
$K_{\mathrm{S}}, 10^{5} \cdot \mathrm{M}^{-1}$ & 1.3 & 3.2 & 1.9 \\
\hline
\end{tabular}

* $\Delta H$ - change of enthalpy upon complex formation with DNA, $\Delta S$ - change of entropy upon complex formation with DNA, $\Delta G$ - change of Gibbs free energy upon complex formation with DNA, $K_{\mathrm{S}}$ - DNA binding constant was determined by spectrophotometric titration. 


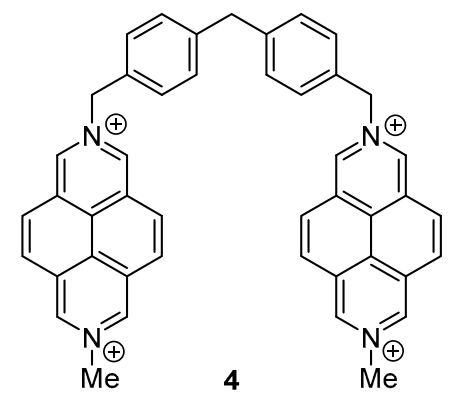

Figure 1. Bis(2,7-diazapyrenium) dication 4.

stable DNA duplex with complementary strand compared to unmodified oligonucleotides.

\section{Scheme 1}

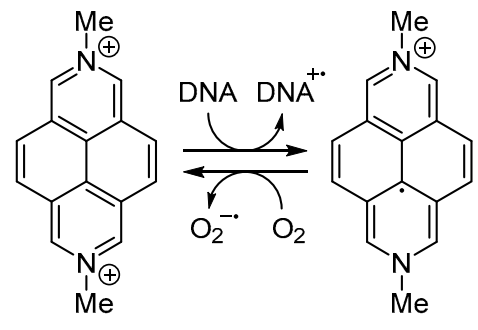

3

DNA cleavage occurs, most likely, through photooxidation of the ribose fragment, followed by hydrolysis of the phosphoester bond. The oxidation mechanism includes the excitation of the 2,7-diazapyrenium dication to the singlet state and the formation of an ion-radical pair with nucleic acid bases due to the single-electron transfer reaction (Scheme 1). Further, the radical cation of 2,7-diazapyrenium dication can be oxidized to a dication with the formation of active forms of $\mathrm{O}_{2}{ }^{40}$

The ease of the reduction of the quaternary salts of 2,7-diazapyrenium dication is most likely due to the stability of the corresponding radical cation and low reduction potential in comparison with structurally similar compounds $^{41}$ (Table 2). The radical cation of 2,7-diazapyrene was characterized by UV spectroscopy and EPR spectroscopy. The intense fluorescence of 2,7-diazapyrenium salts observed in dilute aqueous solutions is quenched by DNA intercalation due to the separation of electrons from neighboring nucleotides. $^{40 \mathrm{a}, 42}$

DNA photooxidation with the formation of radical ion pairs also occurs with the participation of naphthalene$1,4,5,8$-tetracarboxylic acid diimides (NDIs). ${ }^{43}$ In the case of $N, N^{\prime}$-(3-hydroxypropyl)diimide of naphthalene-1,4,5,8tetracarboxylic acid, mainly guanosine-5'-monophosphate and adenosine-5'-monophosphate undergo oxidation. Oxidation of nucleotides $\mathrm{G}$ and $\mathrm{A}$ in DNA using dication 5 containing dimethylamino groups occurs via the singlet excited state, while dianion $\mathbf{6}$ with phosphate groups (Fig. 2) oxidizes nucleotides $\mathrm{G}$ and $\mathrm{A}$ through the triplet excited state. $^{44}$ It is also noted that
Table 2. Redox potential of $N, N^{\prime}$-dimethyl-2,7-diazapyrenium dication (3) and similar dications

\begin{tabular}{cc}
\hline Cation & Redox potential, $\mathrm{V}$ \\
\hline
\end{tabular}

photooxidation of thymine dimer using NDI opens the cyclobutane ring. The destruction of the thymine dimer occurs either by direct photooxidation or by charge transfer using DNA over a distance of $22 \AA$ between the NDI and the cyclobutane ring. ${ }^{45}$

4,9-Diazapyrenium salts form complexes with nucleic bases with a stoichiometry of $1: 1 \quad\left(\log K_{\mathrm{s}}\right.$ 1.6-2.8). The prevalence of aromatic $\pi$-stacking over electrostatic interaction in the stabilization of such complexes was established. The large aromatic system of 4,9-diazapyrenium, compared with ethidium bromide (7), does not cause a significant increase in the binding constant with nucleotides $\left(\log K_{\mathrm{s}}<1-2.3\right) .{ }^{46}$ However, ethidium bromide (7) binds single-stranded polynucleotides 100-1000 times less efficiently than its structural analog 8, the affinity of salts 7 and $\mathbf{8}$ (Fig. 3) for dsDNA and dsRNA turned out to be approximately equal (binding constants were determined by fluorimetric titration). ${ }^{47}$ The presence of substituents in the 4,9-diazapyrenium system does not significantly affect binding to nucleotides, with the exception of two phenyl groups that reduce affinity, probably due to steric interference. ${ }^{48}$

Bis(4,9-diazapyrenium) cation 9 (Fig. 3) forms monointercalated complexes with dsDNA and dsRNA. ${ }^{49}$ Additional interactions of the nonintercalated part are largely dependent on the secondary structure of the polynucleotide. Cation 9 exhibits a greater affinity for

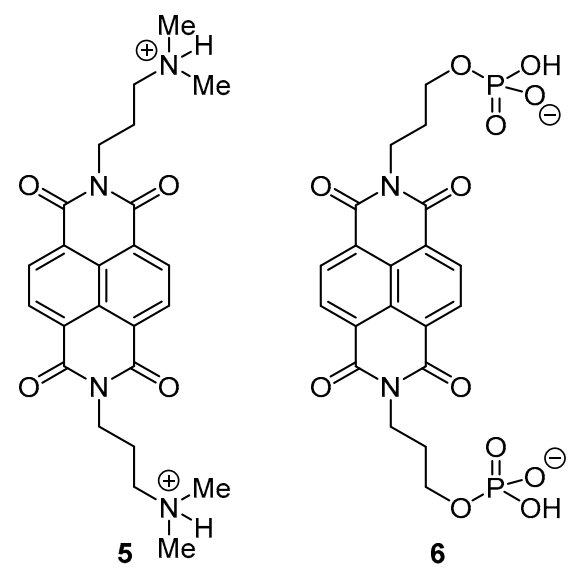

Figure 2. NDI-based dication 5 and dianion $\mathbf{6}$ used to oxidize G and A nucleotides in DNA. 
<smiles>CC[n+]1c(-c2ccccc2)c2c(c3c1=CC(N)=CC3)CC=C(N)C=2</smiles><smiles>C[n+]1c(-c2ccccc2)c2cc(N)cc3nc(-c4ccccc4)c4cc(N)cc1c4c32</smiles>

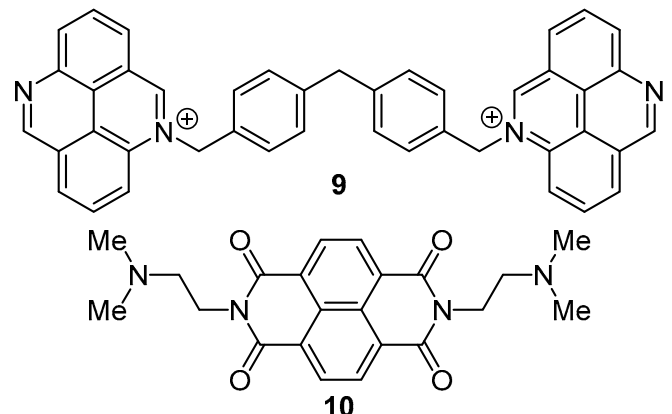

Figure 3. Ethidium bromide (7), its structural analog 4,9-diazapyrenium hydrosulfate $\mathbf{8}$, bis(4,9-diazapyrenium) cation $\mathbf{9}$, and 2,7-diazapyrene derivative 10, which form complexes with nucleic bases.

DNA than for RNA, due to significant differences in the structure of the helix. ${ }^{50}$
Derivatives of 2,7-diazapyrene and NDI are characterized, as a rule, by higher binding constants with DNA than 2,7-diazapyrenium salts. It was shown that the binding strength of compound $\mathbf{1 0}$ (Fig. 3) with DNA depends on the nucleotide composition, the complex of 2,7-diazapyrene 10 with poly $(\mathrm{G}-\mathrm{C})_{2}$ being 20-25 times more stable than complex with poly $(\mathrm{A}-\mathrm{T})_{2}{ }^{51}$

The selectivity of binding of macrocyclic NDIs 11-17 (Fig. 4) with quadruplex DNA is higher than that of the noncyclic derivative $\mathbf{5 a}$, which is most likely caused by steric destabilization of the NDI complex with dsDNA ${ }^{52}$ (Table 3).

The binding of macrocyclic derivatives $\mathbf{1 1}$ and $\mathbf{1 2}$ to the double helix of DNA was proved by circular dichroism spectroscopy and inhibition of topoisomerase I. Thermodynamic parameters $(\Delta G, \Delta H$, and $\Delta S)$ show that exothermic and entropy-dependent hydrophobic binding were crucial for interaction with DNA (Table 4). Due to the longer linker, compound 11 showed a higher binding selectivity, more entropyfavorable interaction and much slower dissociation from complexes with dsDNA than compound $\mathbf{1 2}$ (binding constants were determined by spectrophotometric titration). ${ }^{53}$<smiles>CN(C)CCCN1C(=O)c2ccc3c4c(ccc(c24)C1=O)C(=O)N(CCCN(C)C)C3=O</smiles><smiles></smiles>

11

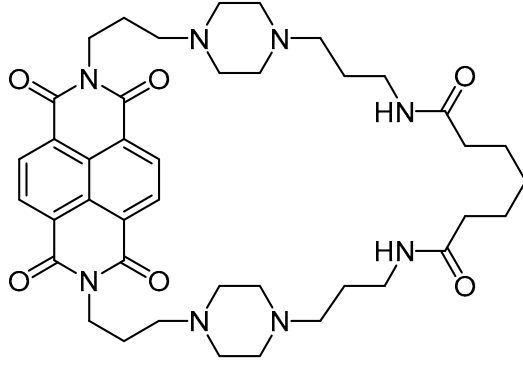

13<smiles>O=C(NCCCN1CCN(CCCN2C(=O)c3ccc4c5c(ccc(c35)C2=O)C(=O)N(CCCN2CCN(CCCNC(=O)c3ccccc3)CC2)C4=O)CC1)c1ccccc1</smiles>

15<smiles>CN(C)CCCN1C(=O)c2ccc3c4c(ccc(c24)C1=O)C(=O)N(CCCN1CCCNC(=O)CC2(CCCCC2)CC2(CCCCC2)CC(=O)CN(C)CCC1)C3=O</smiles>

14

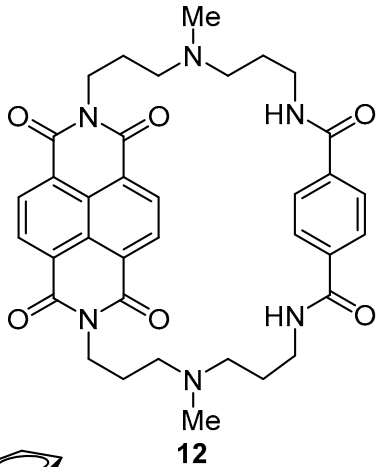

Figure 4. Derivative of NDI 5a containing diamino groups and macrocyclic NDI derivatives 11-17. 
Table 3. Binding constants of NDIs 5a and 11-17 with G4 and dsDNA

\begin{tabular}{ccc}
\hline \multirow{2}{*}{ Compound } & \multicolumn{2}{c}{$K_{\mathrm{S}}{ }^{*}, 10^{6} \mathrm{M}^{-1}$} \\
\cline { 2 - 3 } & $\mathrm{G} 4$ & $\mathrm{dsDNA}$ \\
\hline $\mathbf{1 1}$ & 1.4 & 1.0 \\
$\mathbf{1 2}$ & 3.7 & 2.6 \\
$\mathbf{1 3}$ & 0.5 & 0.12 \\
$\mathbf{1 4}$ & 6.3 & 0.007 \\
$\mathbf{1 5}$ & 2.0 & 1.0 \\
$\mathbf{1 6}$ & 3.4 & 0.075 \\
$\mathbf{1 7}$ & 8.6 & 0.33 \\
\hline
\end{tabular}

* Determined by spectrophotometric titration.

Compound 12 exhibits a high affinity for binding to DNA G4 $\left(K_{\mathrm{S}} 10^{6}-10^{7} \mathrm{M}^{-1}\right)$ in comparison with dsDNA. The binding constants of NDI derivative 12 with G4 of various types (human telomeric DNA, quadruplexes in the promoter region of the KRAS, $c-M Y C$, and thrombinbinding aptamer genes) are up to 270 times greater than the binding constant of NDI 12 with dsDNA (binding constants were determined by spectrophotometric titration). ${ }^{53 \mathrm{~b}}$

The electrostatic interaction of the side chain of NDI with DNA makes a significant contribution to the stability of the intercalation complex. For the quaternary ammonium salt with cation $\mathbf{5}, K_{\mathrm{S}}$ equals $6.6 \cdot 10^{6} \mathrm{M}^{-1}$. A negatively charged phosphate group destabilizes the complex $\left(K_{\mathrm{S}}<10^{2} \mathrm{M}^{-1}\right.$ for the complex with cation 6 (Fig. 2)) (binding constants were determined by spectrophotometric titration). ${ }^{44}$ Moreover, the nature of substituents of the quaternary ammonium has a great influence on the binding of cations 18-21 to DNA. As the size of the substituent increases, the binding constant with dsDNA accordingly increases ${ }^{54}$ (Table 5).

The role of the imidazolyl fragment of the side chain of NDI in DNA intercalation was investigated using UV spectroscopy, competitive binding and fluorescence dye bias analysis, circular dichroism, isothermal calorimetry, and computational analysis. The studies revealed ligand 22 (Fig. 5), which forms a complex with dsDNA, characterized by a half-life of $51 \mathrm{~min}$, which was determined using the dissociation kinetic analysis.

Table 4. Thermodynamic parameters of DNA complexes with NDIs 5a, 11, and $\mathbf{1 2}$

\begin{tabular}{lccc}
\hline \multirow{2}{*}{ Parameter } & \multicolumn{3}{c}{ Compound } \\
\cline { 2 - 4 } & $\mathbf{5 a}$ & $\mathbf{1 1}$ & $\mathbf{1 2}$ \\
\hline$\Delta H, \mathrm{kcal} \cdot \mathrm{mol}^{-1}$ & $-6.7 \pm 0.7$ & $7.8 \pm 1.0$ & $9.2 \pm 1.0$ \\
$\Delta S, \mathrm{cal} \cdot \mathrm{mol}^{-1}$ & $3.0 \pm 2.0$ & $53.0 \pm 3.3$ & $54.0 \pm 3.0$ \\
$\Delta G, \mathrm{kcal} \cdot \mathrm{mol}^{-1}\left(25^{\circ} \mathrm{C}\right)$ & -7.6 & -8.0 & -7.0 \\
\hline
\end{tabular}

Table 5. Binding constants of NDIs 18-21 with dsDNA

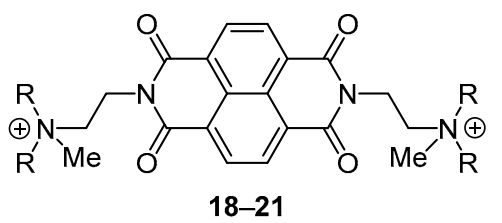

\begin{tabular}{ccc}
\hline Cation & $\mathrm{R}$ & $K_{\mathrm{S}}^{*}, 10^{6} \mathrm{M}^{-1}$ \\
\hline $\mathbf{1 8}$ & $\mathrm{Me}$ & $15 \pm 3$ \\
$\mathbf{1 9}$ & $\mathrm{Et}$ & $31 \pm 8$ \\
$\mathbf{2 0}$ & $n-\mathrm{Pr}$ & $43 \pm 9$ \\
$\mathbf{2 1}$ & $n-\mathrm{Bu}$ & $78 \pm 23$ \\
\hline
\end{tabular}

* Determined by isothermal titration calorimetry.

Computational simulation confirmed the intercalation of the naphthalene ring between the base pairs and the binding of the imidazolyl fragment to the grooves in DNA through electrostatic interaction and hydrogen bonding. As shown by experimental and calculated data, the interaction of positively charged imidazolium fragments with a negatively charged phosphate backbone of DNA contributes to a favorable change in enthalpy. In addition, intercalation caused a significant slowdown of the DNA band when analyzing changes in electrophoretic mobility. ${ }^{55}$

In contrast to $N, N^{\prime}$-disubstituted analogs, 4- and 4,9-substituted NDIs 23 and 24 (Fig. 6) form more stable complexes with dsDNA and also show significant selectivity with respect to G4. ${ }^{56}$ Selectivity is associated on the one hand with unfavorable steric effects in complexes with dsDNA. On the other hand, electrostatic interactions and the formation of hydrogen bonds between phosphate groups in DNA and amino groups in the side chains stabilize G4. ${ }^{57}$

Another water-soluble 4-substituted NDI chelates the $\mathrm{Cu}^{2+}$ ion, and the resulting complex 25 (Fig. 7) is able to bind to G-quadruplex DNA. ${ }^{58}$ In addition, complex 25 is capable of reducing $\mathrm{H}_{2} \mathrm{O}_{2}$ in the presence of sodium ascorbate to form active $\mathrm{O}_{2}$ forms that do not diffuse in solution and cleave DNA in G4 units. Selective cleavage of G4 DNA was also observed for the LTR-III16 and un2 sequences in DNA of respectively HIV-1 and HSV $-1 .{ }^{12 a, 58}$

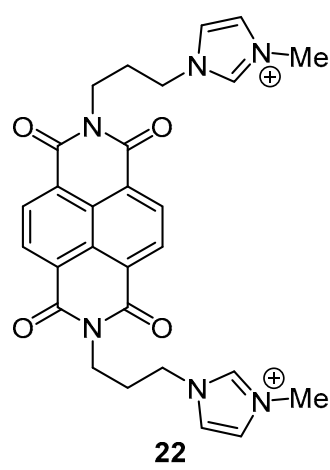

Figure 5. NDI-based ligand 22 containing an imidazolium fragment and forming a complex with dsDNA. 
<smiles>[R]Nc1cc2c3c(ccc4c3c1C(=O)N([R1])C4=O)C(=O)N([R])C2=O</smiles>

23<smiles>[R]Nc1cc2c3c(c(N[R])cc4c3c1C(=O)N([R1])C(=O)C4=O)C(=O)N([R1])C2=O</smiles>

24

$$
\mathrm{R}^{1}, \mathrm{R}^{2}=
$$

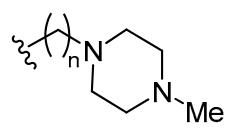

Figure 6. NDIs 23 and 24, which form complexes with dsDNA.<smiles>CN(C)CCN1C(=O)c2ccc3c4c(ccc(c24)C1=O)C(=O)N(CCN(C)C)C3=O</smiles>

25<smiles>CN(C)CCn1c(=O)c2ccc3sc4ccccc4c4ccc(c1=O)c2c34</smiles>

26
Figure 7. Complex 25 of 4-substituted NDI with $\mathrm{Cu}^{2+}$ ion, which interacts with G-quadruplex DNA, and imide 26, participating in nonoxidative hydrolysis of DNA and RNA.

On the other hand, Young et al. showed that the dimethylaminoethyl fragment of compound 26 (Fig. 7) is involved in the nonoxidative hydrolysis of DNA and RNA at the sites 5'-GG-3 'and 5' GC-3'. ${ }^{59}$

Compounds 27 and 28 (Fig. 8) were used as highly effective $\mathrm{O}_{2}$ photosensitizers for photooxidation of 1,5-dihydroxynaphthalene and 3,3'-(anthracene-9,10-diyl)dipropionic acid with singlet oxygen $\left({ }^{1} \mathrm{O}_{2}\right) .{ }^{60}$

Bis(hydroperoxy) derivative of NDI 29 (Fig. 9) specifically cleaves dsDNA in the 5' site of the 5'-GG-3' sequence by the action of UV radiation. Breaking of the DNA chain occurs by the action of hydroxyl radicals formed during the photolysis of diimide 29. It is interesting that upon irradiation of derivatives $\mathbf{3 0}$ and $\mathbf{3 1}$ (Fig. 9), DNA cleavage is not observed even in the presence of piperidine. $^{61}$

The binding constant for supramolecular complex 32 of platinum and the 2,7-diazapyrene ligand (Fig. 9) with dsDNA is an order of magnitude higher than that of the free ligand $\left(K_{\mathrm{S}} 7 \cdot 10^{6}\right.$ and $5 \cdot 10^{5} \mathrm{M}^{-1}$, respectively, binding constants were determined by fluorimetric titration).<smiles></smiles>

27

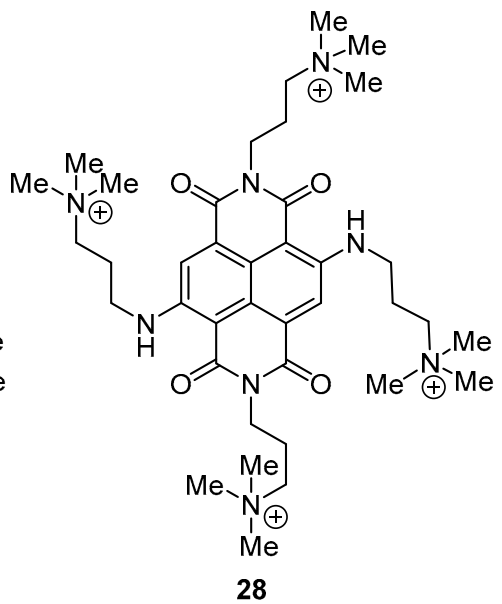

Figure 8. NDIs 27 and 28, highly effective $\mathrm{O}_{2}$ photosensitizers.<smiles>COC(O)CN1C(=O)c2ccc3c4c(ccc(c24)C1=O)C(=O)N(CC(OC)OC)C3=O</smiles>

29<smiles>COC(CN1C(=O)c2ccc3c4c(ccc(c24)C1=O)C(=O)N(CC(OC)OC)C3=O)OC</smiles>

30<smiles>CC(C)CN1C(=O)c2ccc3c4c(ccc(c24)C1=O)C(=O)N(CC(C)C)C3=O</smiles>

31

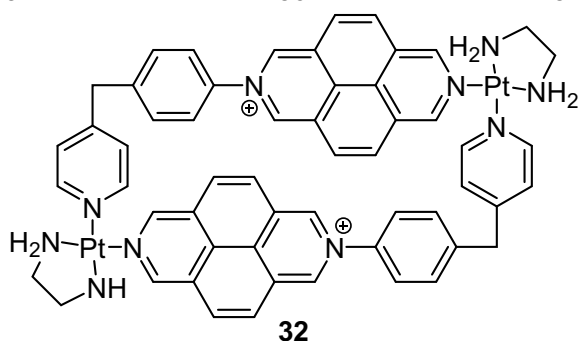

Figure 9. Bis(hydroperoxy) derivative of NDI 29 and its structural analogs $\mathbf{3 0}$ and $\mathbf{3 1}$ used in the study of dsDNA cleavage by UV radiation and a supramolecular complex 32 of platinum and a 2,7-diazapyrene ligand that binds to dsDNA.

Inhibition of polymerase chain reaction (PCR) by complex 32 at concentrations higher than $0.1 \cdot 10^{-6} \mathrm{M}$ is explained by the malfunction of Taq polymerase upon binding of complex 32 to DNA. ${ }^{62}$

NDI-based ligand 33 (Fig. 10) and its complex with $\mathrm{Zn}^{2+}$ ions were studied with respect to the telomeric sequences TAGGG(TTAGGG) $)_{3}$ and AGGG(TTAGGG) $)_{3}$, which form different G4 structures depending on conditions. Both compounds have high binding constants with the hybrid type $\mathrm{G} 4$ formed in the presence of $\mathrm{K}^{+}$ions: $K_{\mathrm{S}}(1.1-2.8) \cdot 10^{6}$ and (6.1-9.1) $10^{6} \mathrm{M}^{-1}$ for ligand 33 and its complex, respectively (binding constants were determined by spectrophotometric titration). The higher affinity for DNA of the complex formed from $\mathrm{Zn}^{2+}$ ions and ligand $\mathbf{3 3}$ is 
<smiles>CN(CCCN(Cc1ccccn1)Cc1ccccn1)CCCN1C(=O)c2ccc3c4c(ccc(c24)C1=O)C(=O)N(CCCN(C)Cc1ccccn1)C3=O</smiles>

Figure 10. NDI-based ligand $33, \mathrm{Zn}^{2+}$ complex of which binds to DNA.

likely due to the formation of an additional electrostatic or coordination interaction between positively charged $\mathrm{Zn}^{2+}$ ions and negatively charged phosphate groups of DNA. ${ }^{63}$

NDI-based tetradentant intercalators with peptide linkers are able to specifically bind to specific sequences in the DNA nucleotide chain. Ligand 34 (Table 6) selectively intercalates the GATAAGTACTTATC sequence, the complex with which is $4 \cdot 10^{4}$ times more stable than a random nucleotide sequence. Kinetic studies have shown a multistep association process with a specific sequence. The dissociation rate constant of the limiting stage of dissociation of ligand complex 34 with DNA is extremely small and corresponds to a half-life of 16 days. ${ }^{64}$ The study of the intercalation complex by NMR spectroscopy showed that NDI fragments are located between the base pairs, and the peptide linker is alternately in minor, major, and minor grooves. ${ }^{65}$ It was found that the rate of association of the intercalator with DNA depends on the structure of the peptide linker, but not the nucleotide sequence. The overall $C_{2}$ symmetry of DNA-binding cation 34, apparently, contributes to a higher rate of association, compared with asymmetric ligands $\mathbf{3 5}$ and $\mathbf{3 6}$ (Table 6). At the same time, the dissociation rate constant depends on the nucleotide sequence: the replacement of one or two nucleotides leads to a significant (up to 30 times) change in the dissociation rate. $^{66}$

NDI derivative 37 containing a chiral epoxy group (Fig. 1) selectively alkylates a guanine fragment in DNA, and in the sequence 5'-GG-3', $(S)$-epoxide alkylates the $5^{\prime}-\mathrm{G}$ site, whereas the $(R)$-epoxide - only the 3 '-G site. ${ }^{67}$

Based on naphthalene-1,4,5,8-tetracarboxylic acid $N, N$ '-bis-[3-(1H-imidazol-1-yl)propyl]diamide complex with ruthenium 38 (Fig. 11), an ultrasensitive mRNA biosensor was developed. ${ }^{68}$ The affinity of NDI derivatives with a ferrocene fragment for DNA duplexes and quadruplexes was used in biosensors to determine dsDNA, ${ }^{69}$ and the affinity for DNA-RNA heteroduplex was employed for determination of $\mathrm{mRNA}^{70}$ and telomerase activity. ${ }^{71}$

Takenaka et al. developed an electrochemical hybriddization method for the analysis of a single-nucleotide polymorphism or deletion in the human lipoprotein lipase gene. PCR products of 350 base pairs containing a wild or mutated type sequence were hybridized with a 13 or 15 base DNA probe immobilized on a gold electrode, then differential pulse voltammetry was performed before and after hybridization in the presence of ferrocenyl naphthalene diimide. $^{72}$

Table 6. Tetradentant intercalators 34-36 based on NDI with peptide linkers

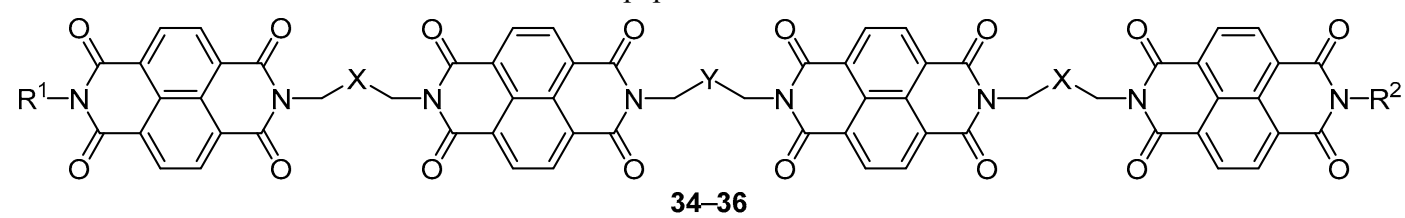

Substituent



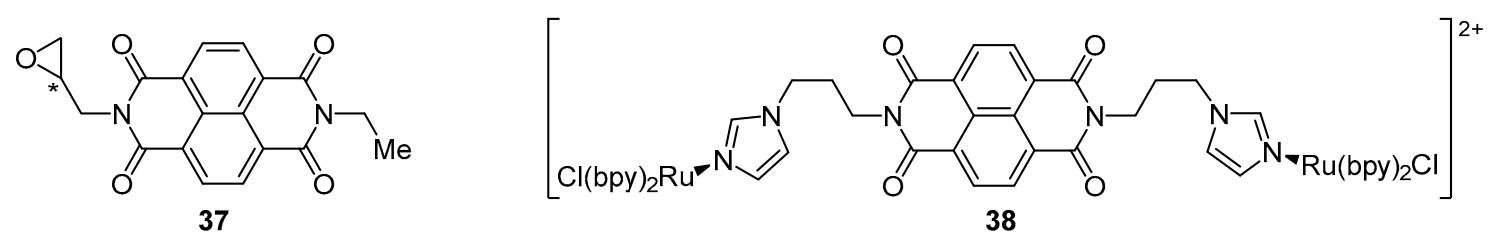

Figure 11. The NDI derivative 37, selectively alkylating the guanine fragment in DNA, and naphthalene-1,4,5,8-tetracarboxylic acid $N, N^{\prime}$-bis[3-(1H-imidazol-1-yl)propyl]diamide complex with ruthenium 38, on the basis of which an ultrasensitive mRNA biosensor has been developed.

The ferrocenyl intercalator was investigated to develop an electrochemical DNA biosensor using a peptide nucleic acid (PNA) sequence as a capture probe. After hybridization with a single-stranded DNA sequence, an intercalator carrying ferrocene fragments was introduced to bind to the PNA-DNA duplex, and the electrochemical signal of ferrocene molecules was used to control DNA recognition. The developed biosensor demonstrated a linear dependence of the oxidation peak of ferrocenyl naphthalene diimide on the concentration of the target DNA in the range from $10^{-15}$ to $10^{-10} \mathrm{M}$ with a detection limit of $11.68 \cdot 10^{-15} \mathrm{M}^{73}$

\section{BIOLOGICAL ACTIVITY OF DIAZAPYRENES}

\subsection{Antiproliferative and antitumor activity of diazapyrenes}

Hannon et al. reported on the in vitro antiproliferative effect of the metal complex $\mathbf{3 2}$ (Fig. 9). The antiproliferative activity of complex $\mathbf{3 2}$ against tumor cell lines (SISO, A-427, LCLC 103H, and 5637) was higher than that of the free ligand (half maximal inhibitory concentration $\left(\mathrm{IC}_{50}\right)(3.1-19.2) \cdot 10^{-6}$ and $>20 \cdot 10^{-6} \mathrm{M}$, respectively). The metal complex $\mathbf{3 2}$ showed antiproliferative activity at the level of cisplatin, but with a different spectrum of activity. ${ }^{62}$

The antiproliferative activity of $N, N^{\prime}$-dimethyl-4,9-diazapyrenium dication derivatives 39-41 (Fig. 12) was studied in vitro on four cell lines: $\mathrm{SKBr} 3, \mathrm{HeLa}, \mathrm{CaCo} 2$, and SW620. The growth inhibition effect was dosedependent and specific for different cell lines. The most pronounced antiproliferative effect at a concentration of $10^{-5} \mathrm{M}$ was observed on SKBr3 cells (91.8 and $85.3 \%$ for cations 40 and 41, respectively) and on SW620 cells (65.3\% for cation 39). The $\mathrm{IC}_{50}$ for the studied compounds

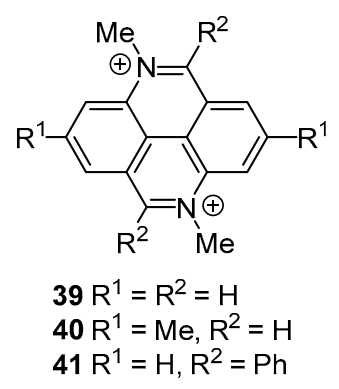

Figure 12. $N, N^{\prime}$-Dimethyl-4,9-diazapyrenium cations 39-41, which are part of compounds tested for antiproliferative activity. was in the range of $0.29-52.2 \mu \mathrm{g} / \mathrm{ml}$. Based on the specific fragmentation of DNA, morphological changes (reduced cell volume, round shape of cells, condensed chromatin), and inhibition of the growth of treated human tumor cells, it is assumed that the tested compounds induced apoptotic cell death. ${ }^{74}$

2,7-Diamino-4-methyl-5,10-diphenyl-4,9-diazapyrenium chloride inhibits the growth of tumor cells with an $\mathrm{IC}_{50}$ in the micromolar range for most of the tested tumor cells, with the exception of glioma cells for which the $\mathrm{IC}_{50}$ is in the submicromolar range. ${ }^{75}$ In addition, 2,7-diamino-4-methyl5,10-diphenyl-4,9-diazapyrenium hydrosulfate (8) (Fig. 3) exhibits fluorescence in the visible spectrum $(\lambda 610 \mathrm{~nm})$, which makes it possible to track the drug in a living cell using fluorescence microscopy. It was noted that the main part of 4,9-diazapyrenium is localized in the cell nucleus. ${ }^{76}$

The cations of bis(4,9-diazapyrenium) salts $\mathbf{9 , 4 2}$, and $\mathbf{4 3}$ (Fig. 13) showed antiproliferative activity similar to monomeric derivatives. This observation, together with the DNA or RNA binding assays described above, convincingly indicates that the studied compounds owe their antiproliferative activity to the interaction with DNA and/ or RNA within the cell. ${ }^{49}$

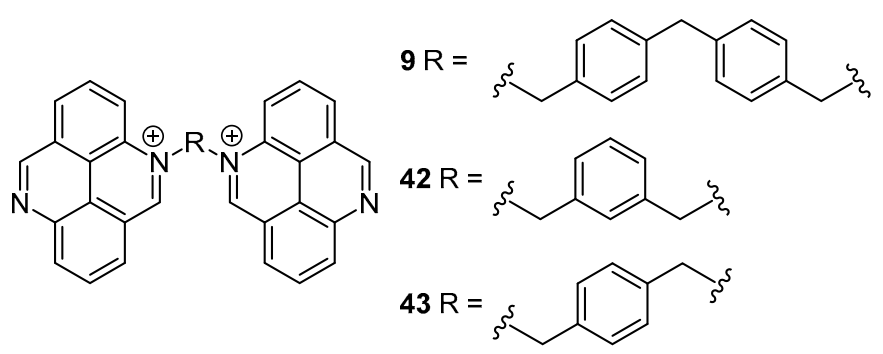

Figure 13. Cations of bis(4,9-diazapyrenium) salts $\mathbf{9 ,} \mathbf{4 2}$, and $\mathbf{4 3}$ with antiproliferative activity.

The mechanisms underlying the antiproliferative activity of 4,9-diazapyrenium salts are still not fully understood. It was shown that 2,7-diamino-4-methyl-5,10-diphenyl-4,9-diazapyrenium chloride significantly reduces cell clonogenicity and blocks cell proliferation in the G1 phase and also causes the induction of $\mathrm{p} 53$ and $\mathrm{p} 21$ proteins, which indicates the activation of the reaction of damaging DNA. However, growth inhibition does not require the implementation of the p53 mechanism, since pairs of isogenic p53+/- cells exhibit the same sensitivity. ${ }^{75}$ Despite the fact that 2,7-diamino-4-methyl-5,10-diphenyl-4,9-diazapyrenium hydrosulfate (8) (Fig. 3) intercalates DNA and RNA, it 
does not inhibit topoisomerase II. Most likely, its biological effect is due to impaired expression of the $K R A S$, $c-N$-ras, cmos, and caspase-3 genes, which probably triggers the apoptosis process. ${ }^{76}$ On the other hand, structurally close 4,9-dimethyl-5,10-diphenyl-4,9-diazapyrenium bishydrosulfate inhibits topoisomerase II, which causes the accumulation of DNA breaks and apoptosis of tumor cells. ${ }^{77}$

In light of the available data on the regulatory role of G4 sequences in the KRAS gene, ${ }^{78}$ a possible relationship between the expression of the KRAS gene and the binding of 2,7-diamino-4-methyl-5,10-diphenyl-4,9-diazapyrenium cation to G4 located above the initial region of the transcription site. The driving force behind the stabilization of the 4,9-diazapyrene - DNA G4 complex may be the presence of substituents at positions 4,5 , and 10 , as was shown for 4,9-disubstituted NDIs. ${ }^{57}$ In addition, quinolinium salts with high affinity for G4 sites also have a strong antiproliferative effect on glioma cells and increase the expression of the caspase- 3 gene. ${ }^{79}$

A series of NDIs 5a, 22, 44, and 45 that selectively bind to the hybrid form of human telomeric G4 in potassium phosphate buffer are described. The most selective ligand for this G4 is conjugate $\mathbf{4 4}$ based on mannose against a number of other quadruplex and duplex structures. Despite this, however, it did not show high antiproliferative activity. It was shown that ligand 45 containing the methylpiperazine fragment was more toxic for HeLa tumor cells than doxorubicin, although it was three times less toxic to lung fibroblasts of the human embryo WI- $38^{80}$ (Table 7).

The ability of tetracation 46 (Fig. 14) to sensitize ${ }^{1} \mathrm{O}_{2}$ is of interest for its application in photodynamic therapy. In addition, intense fluorescence in the red and near infrared ranges makes it possible to control penetration into cells and accumulation of tetracation $\mathbf{4 6}$ within the nuclei. The tetracation exhibits potential bimodal activity as a fluorescent probe and photosensitizer of reactive oxygen species when excited by light entering the so-called therapeutic window of photodynamic therapy. In the absence of light, antiproliferative effects were not observed on tumor cell lines. Irradiating the loaded NDI cells with red light reduces cell viability by up to $40 \%$ and causes a significant increase in the proportion of cells expressing $\gamma \mathrm{H} 2 \mathrm{AX}$ foci, which indicates DNA damage. The presence of distinct foci of DNA damage within the nucleus suggests that NDI cation 46 is capable of causing DNA damage in certain sequences. $^{81}$

NDI polyamine derivatives inhibit topoisomerase II and Taq polymerase $\left(\mathrm{IC}_{50}(2.2-8.1) \cdot 10^{-6}\right.$ and $(0.25-10) \cdot 10^{-6} \mathrm{M}$, respectively), and can have an antiproliferative effect on<smiles>CN(C)CCNc1cc2c3c(c(NCC[N+](C)(C)C)cc4c3c1C(=O)N(CCN(C)C)C(=O)C4=O)C(=O)N(CC[N+](C)(C)C)C2=O</smiles>

Figure 14. NDI tetracation 46 sensitizing ${ }^{1} \mathrm{O}_{2}$ and causing DNA damage in specific sequences.

Table 7. Stabilization of telomeric G4 F21T in potassium phosphate buffer and antiproliferative activity of NDIs 5a, 22, 44, and 45 in relation to WI-38, HeLa, MCF7, MDA-MB-231 cell lines

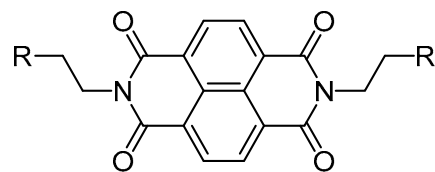

5a, 22, 44, 45

\begin{tabular}{|c|c|c|c|c|c|c|}
\hline \multirow{2}{*}{ Compound/cation } & \multirow{2}{*}{$\mathrm{R}$} & \multirow{2}{*}{$\Delta T_{\max },{ }^{\circ} \mathrm{C}$} & \multicolumn{4}{|c|}{$\mathrm{IC}_{50}, 10^{-6} \mathrm{M}$} \\
\hline & & & WI-38 & HeLa & MCF7 & MDA-MB-231 \\
\hline $5 \mathbf{a}$ & & $2.3 \pm 0.5$ & 0.72 & 0.38 & 0.53 & 8.10 \\
\hline 22 & & $3.7 \pm 0.3$ & 40.22 & 3.63 & 11.77 & - \\
\hline 44 & & $10.1 \pm 0.3$ & $>100$ & $>100$ & $>100$ & $>100$ \\
\hline 45 & & $9.8 \pm 0.6$ & 2.28 & 0.41 & 3.09 & 0.81 \\
\hline
\end{tabular}


SR, MDA-MB-468, and MOLT-4 tumor cell lines with submicromolar and nanomolar values of the concentration inhibiting the growth of $50 \%$ of cells $\left(\mathrm{GI}_{50}\right)$. A systematic study of the structure-activity relationship showed that an increase in activity correlates with an increase of the positive charge of the molecule. ${ }^{82}$

Compounds 47-50 are active against tumor cells in submicromolar concentrations with toxicity to normal fibroblast cells WI-38 up to 100 times lower compared to tumor cells (Table 8). Compounds $\mathbf{4 7 - 5 0}$ were found to inhibit topoisomerase III $\alpha$ and telomerases in MCF7 cells. ${ }^{56,83}$ Inhibition of tumor cell growth is probably associated with a suppression of expression of the chaperone protein HSP90, a regulator of telomerase activity ${ }^{84}$ The promoter region of the $H S P 90$ gene contains two G4 sequences, binding to which leads to the suppression of gene expression. Tetrasubstituted NDI $\mathbf{5 0}$ stabilizes telomeric G4 and G4 in the promoter region of the KIT and HIF-1 $\alpha$ oncogenes, as well as G4 in mRNA of the $B C L-2$ gene. ${ }^{85}$ Compound $\mathbf{4 8}$ is capable of initiating aging in tumor cells, probably as a result of telomere conformation disruption by stabilization of G4 and subsequent DNA damage, as demonstrated by the detection of $\gamma$-H2AX foci. In addition, it promotes the fusion of telomeric chromosomes, which leads to genomic instability and subsequent apoptosis. ${ }^{84}$ Using confocal microscopy, it was found that compound $\mathbf{5 0}$ is able to penetrate the cytoplasm and nucleolus of a cell, which causes an increase in telomeric associations in cells that stimulate chromosomal instability. ${ }^{85}$ With parenteral administration, NDI 48 accumulates mainly in tumors and pancreas and to a lesser extent in the lungs. Only trace amounts of NDI 48 were found in the heart, kidneys, liver, and spleen. ${ }^{84}$

Macrocyclic NDIs containing spermidine- and sperminelike side chains stabilize both the KIT2 sequence and telomeric sequences $\left(\Delta T_{\max } 33.1\right.$ and $26.8^{\circ} \mathrm{C}$, respectively), but do not inhibit telomerase. Calculations confirmed that the most stabilizing molecule is also the best G4 binder. On this basis, an assumption was made about the electrostatic effect of the side chains as a driving force of the binding process. At the same time, the antiproliferative effect within cells turned out to be not associated with G4 stabilization (the higher $\Delta T_{\max }$, the lower the antiproliferative effect and vice versa) and does not have cell type selectivity, which is probably due to the physicochemical properties of the molecules. ${ }^{52 \mathrm{c}}$

Amino acid-functionalized NDIs were synthesized and studied as ligands for G4. One of the compounds demonstrated selective stabilization of the KIT2 sequence $\left(\Delta T_{\max } 14.6^{\circ} \mathrm{C}\right)$ in combination with a slight destabilization of the KIT1 sequence in vitro. ${ }^{86}$

The crystal structures of three complexes with telomeric intramolecular human G4 showed that two of the four strongly basic $N$-methylpiperazine groups can be replaced by less basic morpholine groups without the loss of intermolecular interactions in the grooves of G4. The new compounds retain a high affinity for human telomeric quadruplex DNA, but are 10 times more effective against the pancreatic cancer cell line MIA $\mathrm{PaCa}-2$ with $\mathrm{IC}_{50}$
Table 8. Antiproliferative activity of NDIs 47-50 in relation to MCF7, A549, WI-38 cell lines

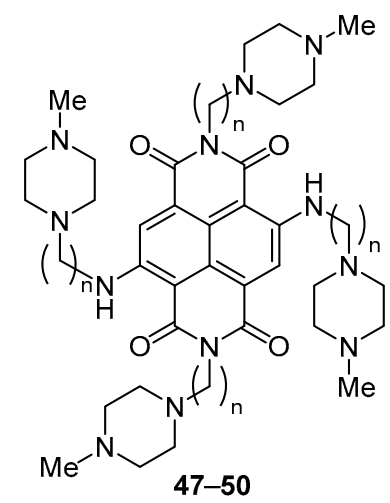

\begin{tabular}{ccccc}
\hline \multirow{2}{*}{ Compound } & $\mathrm{n}$ & \multicolumn{3}{c}{$\mathrm{IC}_{50}, 10^{-6} \mathrm{M}$} \\
\cline { 3 - 5 } & & $\mathrm{MCF7}$ & $\mathrm{A} 549$ & $\mathrm{WI}-38$ \\
\hline $\mathbf{4 7}$ & 2 & 1.01 & 0.47 & 5.59 \\
$\mathbf{4 8}$ & 3 & 0.17 & 0.11 & 9.04 \\
$\mathbf{4 9}$ & 4 & 0.10 & 0.07 & 5.50 \\
$\mathbf{5 0}$ & 5 & 0.20 & 0.26 & 8.43 \\
\hline
\end{tabular}

values of $\sim 10 \mathrm{nM}$. Compound 51 (Table 9) induces cell aging, but does not inhibit telomerase at nanomolar concentrations necessary to inhibit cell proliferation. Realtime PCR analysis of the gene array of MIA PaCa-2 cells treated with compound $\mathbf{5 1}$ revealed significant dosedependent modulation of individual subgroups of genes, including strong induction of genes sensitive to DNA damage (CDKN1A, DDIT3, GADD45A/G, and PPM1D), and gene repression involved in maintaining telomeres, including $h P O T 1$ and $P A R P 1{ }^{87}$

Tetrasubstituted NDI 51 (Table 9) has significant in vivo antitumor activity against the xenograft model of the MIA PaCa-2 pancreatic cancer. Intravenous administration of $15 \mathrm{mg} / \mathrm{kg}$ of compound $\mathbf{5 1}$ twice a week for 40 days causes a decrease in tumor growth to $80 \%$ in the group of animals with tumors. On day 40 of the experiment, in the control group and the group receiving $10 \mathrm{mg} / \mathrm{kg}$ NDI 51, zero survival was observed, while in the group with a $15 \mathrm{mg} / \mathrm{kg}$ dose, 6 out of 8 animals survived, and 2 of them showed complete tumor regression. Further observation of them for 239 days showed no signs of tumor resumption in the absence of drug administration. The accumulation of the drug in the tumor with a primary localization in the cell nucleus was noted. The level of $B C L-2$ gene expression in animal tumors under the action of compound $\mathbf{5 1}$ was reduced to $40 \%$. Based on the data of molecular modeling, the authors hypothesized that ligand $\mathbf{5 1}$ based on NDI binds to $\mathrm{G} 4$ of the $B C L-2$ gene in the same way as previously observed in crystalline structures with human telomeric G4. This confirms the concept that NDI $\mathbf{5 1}$ can bind to promoter regions containing quadruplex sequences and thus inhibit their transcription. ${ }^{88}$ 
Analysis of the structural activity data of tetrasubstituted NDIs 51-55 containing a morpholine fragment shows that compounds with a different number of methylene units in the side chains between the morpholine and $N$-methylpiperazine fragments tend to increase antiproliferative activity and, in some cases, exhibit excellent ability to stabilize G4 DNA (Table 9). However, no clear correlation was found between binding affinity to G4 and biological activity. ${ }^{89}$

A recent work presented trisubstituted NDI 56 (Fig. 15), which exerts an antiproliferative effect on human pancreatic duct adenocarcinoma cell lines. ${ }^{90}$ Its activity was predicted by computer simulation based on the crystal structure of NDI 51 complexed with telomeric quadruplex DNA. ${ }^{87}$ Rationally developed molecule $\mathbf{5 6}$ stabilized G4 in vitro, although not as much as the original molecule 51, and showed significant antiproliferative activity $\left(\mathrm{IC}_{50}\right.$ $\left.(7 \pm 2) \cdot 10^{-9} \mathrm{M}\right)$ on PDAC cell lines. The authors analyzed the global genome transcript using the RNA-seq method to identify all the genes affected by the molecule. Suppression of expression was observed in a complex of genes enriched by the formation of quadruplex sequences. In addition, treatment of cells with compound $\mathbf{5 6}$ leads to an increase in the foci of G4-specific BG4 antibodies and double-stranded DNA damage. ${ }^{90}$

Tetrasubstituted NDI 57 with pyrrolidine fragments stabilizes the KIT2 sequence and telomeric sequence of human DNA with similar $\Delta T_{\max }$ values $\left(29.0\right.$ and $28.7^{\circ} \mathrm{C}$,<smiles>O=C1c2ccc3c4c(c(NCCN5CCCC5)cc(c24)C(=O)N1CCCN1CCOCC1)C(=O)N(CCCN1CCOCC1)C3=O</smiles>

Figure 15. Trisubstituted NDI 56, which has an antiproliferative effect on human pancreatic duct adenocarcinoma cell lines.

respectively). ${ }^{56}$ The antiproliferative activity of compound 57 with respect to the cell lines GIST882, HGC-27, HT-29, and MCF7 was higher, than other G4 ligands, such as BRACO-19 and TMPyP4 (Fig. 16). In addition, NDI 57 reduces the transcription of the KIT gene by $90 \%$ and completely inhibits the expression of this gene at the dosage necessary to obtain an antiproliferative effect in cells $\left(10^{-6} \mathrm{M}\right)$. Given the strong inhibition of telomerase, evaluated using the TRAP-LIG assay, the authors hypothesized a double mode of action, with inhibition of telomerase and suppression of KIT gene expression. ${ }^{91}$

Table 9. Antiproliferative activity of NDIs 51-55 against RCC4, 786-O, MCF7, MIA PaCa-2, A549, and WI-38 cell lines

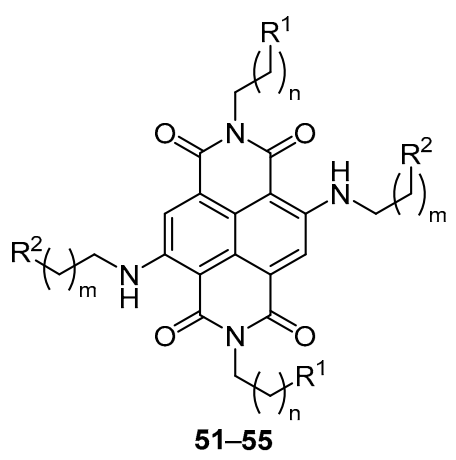

\begin{tabular}{llllllllllllll}
\hline $\begin{array}{c}\text { Com- } \\
\text { pound }\end{array}$ \\
\hline 51
\end{tabular}


The mechanism of action of tetrasubstituted NDIs with pyrrolidine fragments involves binding to G4 DNA in the $B C L-2$ gene and its transcript. Compound 57 strongly stabilizes the G4 series $\left(\Delta T_{\max } 11.2-29^{\circ} \mathrm{C}\right)$, including DNA from the $B C L-2$ promoter and G4 RNA from the 5 -untranslated region, and reduces the production of Bcl-2 protein in imatinib-resistant cells of gastrointestinal stromal tumors. $^{92}$

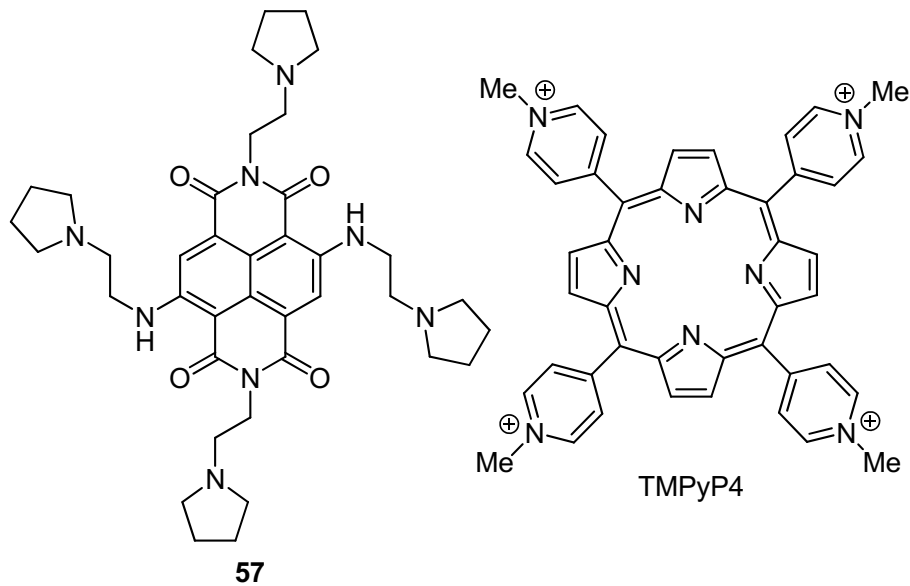<smiles>CC(C)(C)OC(=O)c1ccc(NC(=O)CCN2CCCC2)c2nc3cc(NC(=O)CCN4CCCC4)ccc3c(Nc3ccc(N([N+](=O)[O-])C(C)(C)C)cc3)c12</smiles>

Figure 16. NDI 57 containing pyrrolidine moieties and G4 ligands TMPyP4 and BRACO-19.

Bifunctional compounds containing NDIs and coumarin rings showed activity against six tumor cell lines in the micromolar to submicromolar concentration range. ${ }^{93}$

Bisimidazole ligands based on the NDI ring inhibit the growth of A549, HeLa, and HEK 293T cell lines in the micromolar concentration range. The compound with the methylene linker between the imidazole and naphthalene diimide rings is more active than the derivative with the $p$-phenylene fragment, which is probably due to its increased stabilization. ${ }^{94}$ In addition, these compounds inhibit telomerase and also show less antiproliferative activity with respect to normal cells in comparison with tumor cells. The biological significance of potent imidazolyl-NDI conjugates is determined by the inhibition of topoisomerase I and their cytotoxicity in HeLa cells. ${ }^{95}$

The antiproliferative activity of compounds $\mathbf{5 8}$ (Fig. 17) was studied on SKBR-3, CEM, and HL60 cell lines. It was shown that for the SKBR-3 and CEM lines, the antiproliferative effect of NDIs $\mathbf{5 8}$ is independent of the length of the hydrocarbon linker $\left(\operatorname{IC}_{50}(0.2-1.7) \cdot 10^{-6}\right.$ and $(0.4-2.5) \cdot 10^{-6} \mathrm{M}$, respectively). However, for HL60 cells, compounds $\mathbf{5 8}$ with a short linker turned out to be more

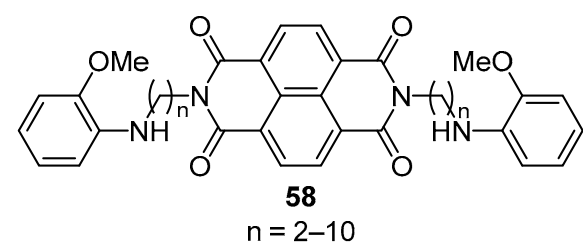

Figure 17. NDI derivatives 58, tested for antiproliferative activity against SKBR-3, CEM, and HL60 cell lines.

active $\left(\mathrm{n}=2\right.$ and $3, \mathrm{IC}_{50} 0.9 \cdot 10^{-6}$ and $1.2 \cdot 10^{-6} \mathrm{M}$, respectively). The mechanism of their action is associated with the activation of caspase, the accumulation of p53 protein, and the suppression of AKT kinase. ${ }^{96}$

Introduction of quaternary salts of Mannich bases, $o$-quinone methide precursors into the structure of NDI made it possible to obtain selective and soft alkylating agents 59-61 (Fig. 18). The alkylation process with compound 59 occurs much more efficiently in the presence of DNA sequences capable of forming G4. ${ }^{97}$ The introduction of alkylamine groups into the structure of NDI significantly increases the antiproliferative effect with respect to cell lines HT-29, A549, and SK-MEL-5 (IC 50

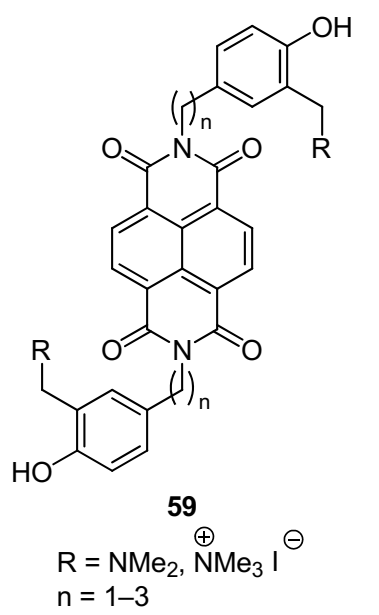<smiles>CON(C)CCN1C(=O)c2ccc3c4c(c(NCCc5ccc(O)c(CN(C)C)c5)cc(c24)C1=O)C(=O)N(CC[N+](C)(C)OC)C3=O</smiles>

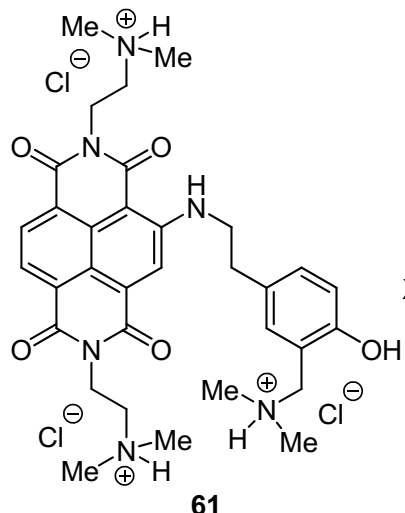

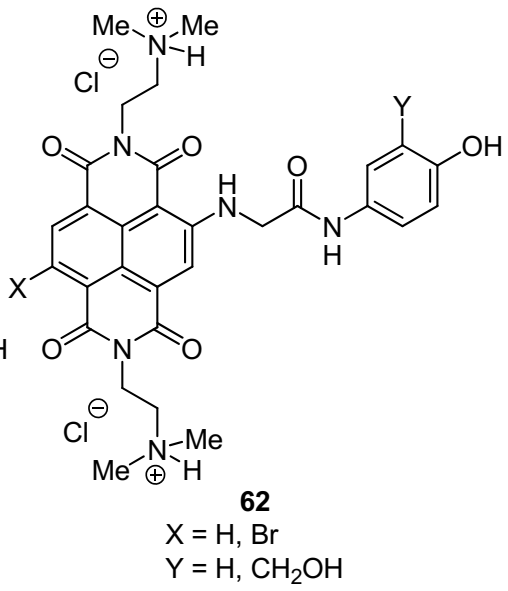

Figure 18. NDI derivatives 59-62 - alkylating agents with antiproliferative properties. 
$\left.(0.4-9) \cdot 10^{-6} \quad \mathrm{M}\right){ }^{98}$ Alkylation of telomeric $\mathrm{G} 4$ by compounds 62 containing an amide fragment (Fig. 18) occurs $100-1000$ times more efficiently than by single and double-stranded oligonucleotides. Their antiproliferative activity against telomerase-positive carcinoma cells was slightly higher than with respect to telomerase-negative cell lines (half-maximum effective concentration $\left(\mathrm{EC}_{50}\right)(1.4$ $27.5) \cdot 10^{-6}$ and $(18-40) \cdot 10^{-6} \mathrm{M}$, respectively). ${ }^{99}$ The antiproliferative effect of compound $\mathbf{6 1}$ is associated with inhibition of the expression of the RET proto-oncogene. Biophysical and reporter gene analysis showed that impaired RET gene expression was due to G4 stabilization in the gene promoter caused by alkylation in the $\mathrm{G} 4$ region. In addition, NDI derivative $\mathbf{6 1}$ inhibits RET gene expression and has an in vivo antitumor effect without obvious signs of general toxicity. ${ }^{100}$

NDIs 64-66 with isothiocyanate groups (Fig. 19), functional analogs of the anticancer agent sulforaphane (63), have shown greater antitumor activity than sulforaphane (63). Compounds 64-66 exhibited antiproliferative activity against the Jurkat cell line of human T-lymphoblastic leukemia in the submicromolar concentration range. It was noted that NDI $\mathbf{6 6}$ inhibits the cell cycle in phase G1. ${ }^{101}$

A number of asymmetric derivatives of NDI were synthesized and evaluated for anticancer properties using various experimental methods. The anticancer effects of these compounds are significantly affected by their substituents. Among the analyzed NDI derivatives, compound 67 (Fig. 19) has a stronger inhibitory effect on SMMC-7721 and Hep G2 hepatoma cells than on nontumor QSG-7701 cells, which indicates the selective action of NDI 67 against hepatoma cells. Compound 67 induces<smiles>CC(=O)NCCCCS(C)=O</smiles><smiles>CN(C)CCN1C(=O)c2ccc3c4c(ccc(c24)C1=O)C(=O)N(CC(=O)O)C3=O</smiles>

64<smiles>O=C1c2ccc3c4c(ccc(c24)C(=O)N1CCN(S)S)C(=O)N(CCN(S)S)C3=O</smiles>

65<smiles>CS(=O)(=O)NCCCN1C(=O)c2ccc3c4c(ccc(c24)C1=O)C(=O)N(CCCNS(=O)(=O)[O-])C3=O</smiles>

66

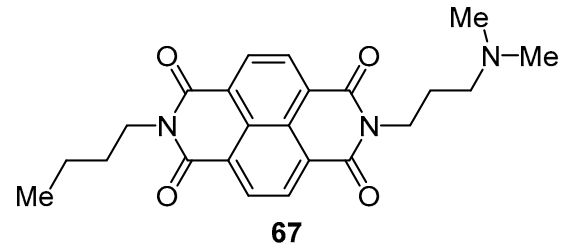

Figure 19. The anticancer agent sulforaphane (63), its functional analogs NDIs 64-66 with isothiocyanate groups, and NDI derivative 67 with selective action against SMMC-7721 and Hep G2 hepatoma cells. autophagy and, in a concentration-dependent manner, inhibits the migration of hepatoma cells as a result of the generation of reactive oxygen species. ${ }^{102}$

A series of hybrid compounds was developed by Milelli et al. to bind histone deacetylases with G-quadruplex DNA by combining the structural elements of scriptaid (68) and NDI in one molecule. The most active of them, compound 69 (Fig. 20), binds various DNA structures, inhibits histone deacetylases both in vivo and in vitro and can cause a decrease in cell proliferation. Moreover, derivative of NDI 69 exhibits the property of reprogramming the cell phenotype - preventing the epithelial-mesenchymal transition in tumor cells, leading to cells of a less aggressive and migratory phenotype. ${ }^{103}$<smiles>NCCCCNCCCCCNCCCN1C(=O)c2ccc3c4c(ccc(c24)C1=O)C(=O)N(CCCCCC(=O)NO)C3=O</smiles>

Figure 20. Scriptaid (68) and its NDI derivative 69 inhibiting histone deacetylase.

NDI-carbohydrate conjugates $\mathbf{7 0 - 7 5}$ showed antiproliferative activity in the micromolar concentration range (Table 10). The carbohydrate moiety appears to improve the intracellular uptake of the active compound. There is a correlation between the intensity of absorption of glycosylated NDI and their high toxicity with respect to tumor cell lines. Carbohydrate NDIs appear to be mainly translocated to tumor cells via glucose transporters, where GLUT4 plays a major role. Interestingly, the addition of a monosaccharide via a short ethylene linker to the NDI ring (compound 74) leads to a 2-3-fold increase in cellular absorption and 5.7-8-fold increase in antiproliferative activity, as compared to compound $\mathbf{7 1}$, where the carbohydrate is attached directly via a glycosidic bond. ${ }^{104}$

\subsection{Antibacterial, antiviral, and antiprotozoal activity of diazapyrenes}

NDI derivatives 76-79 with an extended aromatic ring (Fig. 21) bind and stabilize G4 to a high degree, and some of these compounds showed a certain selectivity for viral G4 compared to human telomeric G4. This feature leads to activity against HIV-1 in the nanomolar concentration range for two strains of the virus. This is one of the first examples of G4 ligands that show increased selectivity for viral G4 and exhibit significant antiviral activity. ${ }^{1 \mathrm{~b}}$

Compound 76 (Fig. 21) was tested for antiviral activity against the HSV-1 herpes virus. It showed greater antiviral activity compared to acyclovir. Treatment of cells infected 
with HSV-1 with NDI $\mathbf{7 6}$ at low concentrations $\left(\mathrm{IC}_{50}\right.$ $\left.(18.3 \pm 1.4) \cdot 10^{-9} \mathrm{M}\right)$ causes significant inhibition of the virus without pronounced signs of cytotoxicity. ${ }^{105}$

Bioinformational analysis of the M. tuberculosis genome revealed more than 10,000 fragments with the potential for the formation of G4 structures. The synthetic ligand for the detected G4 based on NDI $\mathbf{7 6}$ has an antibacterial effect on M. tuberculosis in the submicromolar concentration range (the minimum inhibitory concentration for $80 \%$ of the studied strain $\left.\left(\mathrm{MIC}_{80}\right) 1.25 \cdot 10^{-6} \mathrm{M}\right){ }^{106}$

A theranostic compound containing two vancomycin fragments was synthesized based on the 1,8-diazapyrene ring. The drug exhibits high and selective antibacterial activity against Gram-positive bacteria, including strains resistant to vancomycin, with minimal effect on Gramnegative bacteria and mammalian cells. In addition, this preparation can be used for selective two-photon fluorescence imaging of Gram-positive bacteria. ${ }^{107}$

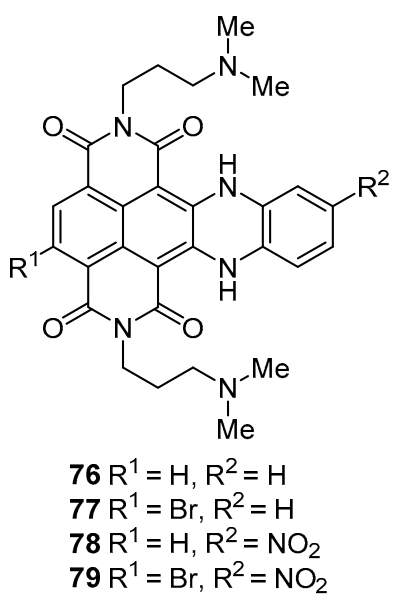

Figure 21. Condensed NDI derivatives 76-79 with antiviral activity.

Table 10. Antiproliferative activity of NDIs 70-75 against HT-29, MCF-7, HeLa, and MRC-5 cell lines

\begin{tabular}{|c|c|c|c|c|c|}
\hline \multirow{2}{*}{ Compound } & \multirow{2}{*}{$\mathrm{R}$} & \multicolumn{4}{|c|}{$\mathrm{IC}_{50}, 10^{-6} \mathrm{M}$} \\
\hline & & HT-29 & MCF-7 & HeLa & MRC-5 \\
\hline 70 & & $2.92 \pm 0.48$ & $1.19 \pm 0.31$ & $1.56 \pm 0.70$ & $1.15 \pm 0.29$ \\
\hline 71 & & $2.26 \pm 1.03$ & $1.06 \pm 0.01$ & $0.95 \pm 0.76$ & $0.51 \pm 0.01$ \\
\hline 72 & & $0.40 \pm 0.08$ & $0.69 \pm 0.71$ & $0.35 \pm 0.05$ & $0.91 \pm 0.32$ \\
\hline 73 & & $1.85 \pm 0.19$ & $1.42 \pm 0.38$ & $0.54 \pm 0.34$ & $2.04 \pm 0.05$ \\
\hline 74 & & $0.42 \pm 0.05$ & $0.15 \pm 0.04$ & $0.29 \pm 0.14$ & $0.81 \pm 0.44$ \\
\hline 75 & & $0.12 \pm 0.02$ & $0.13 \pm 0.07$ & $0.29 \pm 0.18$ & $0.71 \pm 0.25$ \\
\hline
\end{tabular}


A new class of bifunctional molecules 80-82 (Fig. 22) was synthesized by combining acridine and redox-active NDI rings, both directly and through a flexible linker. The adducts with a rigid bond of acridine and NDI showed activity with respect to the chloroquine-sensitive strain of the human malaria pathogen $P$. falciparum in micromolar to submicromolar concentration range (compound 80: $\mathrm{IC}_{50}$ $0.419 \cdot 10^{-6} \mathrm{M}$ ). Compounds with a flexible linker between aromatic rings showed high activity both against chloroquine-sensitive (compounds 81 and 82: $\mathrm{IC}_{50} 4.33 \cdot 10^{-9}$ and $\left.3.65 \cdot 10^{-9} \mathrm{M}\right)$ and against chloroquine-resistant P. falciparum strains (compounds 81 and $\mathbf{8 2}$ : $\mathrm{IC}_{50} 28.53 \cdot 10^{-9}$ and $\left.52.20 \cdot 10^{-9} \mathrm{M}\right)$. $^{108}$<smiles>COc1ccc2nc3cc(Cl)ccc3c(N3C(=O)c4ccc5c6c(ccc(c46)C3=O)C(=O)N(CCN(C)C)C5=O)c2c1</smiles><smiles>CCCN1C(=O)c2ccc3c4c(ccc(c24)C1=O)C(=O)N(CCNc1c2ccc(Cl)cc2nc2ccc(OC)cc12)C3=O</smiles><smiles>COCCN(C)CCN1C(=O)c2ccc3c4c(ccc(c24)C1=O)C(=O)N(CCNc1c2ccc(Cl)cc2nc2cc(OC)ccc12)C3=O</smiles>

Figure 22. Bifunctional acridine-NDI adducts $\mathbf{8 0}-\mathbf{8 2}$ with activity against the human malaria pathogen strain $P$. falciparum.

Ligands 70-75 showed strong antiparasitic activity when tested on $T$. brucei, $L$. major, and $P$. falciparum, whose genomes contain a large number of G4 capable of interacting with ligands (Table 11). $\mathrm{IC}_{50}$ values are in the nanomolar range with high selectivity against $T$. brucei compared to human MRC-5 cells. The data obtained by confocal microscopy indicate the localization of the ligand within the nucleus and kinetoplast of $T$. brucei. Studies of cytotoxicity and toxicity in zebrafish have shown that carbohydrate conjugation significantly reduces the toxicity of compounds. ${ }^{109}$

Bifunctional compounds 83 (Fig. 23) containing NDI and coumarin rings showed a pronounced antibacterial
Table 11. Antiparasitic (against L. major, T. brucei, and $P$. falciparum) and antiproliferative activity (against MRC-5 human diploid cells) of NDIs 70-75

\begin{tabular}{ccccc}
\hline \multirow{2}{*}{$\begin{array}{c}\text { Com- } \\
\text { pound }\end{array}$} & \multicolumn{4}{c}{$\mathrm{IC}_{50}, 10^{-6} \mathrm{M}$} \\
\cline { 2 - 5 } & L. major & T. brucei & P. falciparum & MRC-5 \\
\hline $\mathbf{7 0}$ & $0.244 \pm 0.007$ & $0.024 \pm 0.001$ & $1.350 \pm 0.636$ & $1.15 \pm 0.29$ \\
$\mathbf{7 1}$ & $1.041 \pm 0.027$ & $0.089 \pm 0.007$ & $0.360 \pm 0.071$ & $0.51 \pm 0.01$ \\
$\mathbf{7 2}$ & $0.184 \pm 0.009$ & $0.017 \pm 0.007$ & $0.225 \pm 0.120$ & $0.91 \pm 0.32$ \\
$\mathbf{7 3}$ & $0.921 \pm 0.051$ & $0.099 \pm 0.010$ & $0.370 \pm 0.085$ & $2.04 \pm 0.05$ \\
$\mathbf{7 4}$ & $0.306 \pm 0.019$ & $0.021 \pm 0.003$ & $0.180 \pm 0.099$ & $0.81 \pm 0.44$ \\
$\mathbf{7 5}$ & $0.537 \pm 0.030$ & $0.017 \pm 0.009$ & $0.275 \pm 0.191$ & $0.71 \pm 0.25$ \\
\hline
\end{tabular}

effect (on the level of ciprofloxacin, MIC 18.75-37.5 $\mu \mathrm{g} / \mathrm{ml}$ ) against Gram-positive (S. aureus, S. epidermidis) and Gramnegative (E. coli, $P$. aeruginosa) bacteria. ${ }^{93}$

Chronic H. pylori infection is a major risk factor for gastric cancer. Moreover, infection of tumor cells with H. pylori bacteria makes them more resistant to apoptosis caused by chemotherapy. Compound 84 (Fig. 23) showed growth inhibition of $H$. pylori at a submicromolar concentration (MIC $0.5 \cdot 10^{-6} \mathrm{M}$ ), $50 \%$ growth inhibition was observed at a concentration of $0.1 \cdot 10^{-6}$ M. NDI 84 inhibits bacterial growth in concentrations below its $\mathrm{IC}_{50}$ in gastric cancer cells, thus providing the opportunity to use it as an antibacterial and anticancer agent simultaneously. ${ }^{110}$

NDI 85 (Fig. 23) showed moderate antimicrobial activity against Gram-positive $S$. aureus in nutrient agar (MIC $118 \mu \mathrm{g} / \mathrm{ml}$ ). High activity of NDI $\mathbf{8 5}$ against $S$. aureus was noted in LB medium (MIC $29.4 \mu \mathrm{g} / \mathrm{ml}$ ). Compound 85 inhibits the growth of $E$. coli starting at a concentration of $500 \mu \mathrm{g} / \mathrm{ml}$. This indicates that NDI 85 specifically inhibits the growth of Gram-positive bacteria. In addition, NDI 85 does not lyse red blood cells even at a concentration of $2.5 \mathrm{mg} / \mathrm{ml}$ and shows a higher selectivity for bacterial cells than for mammalian cells $\left(\mathrm{IC}_{50}, 1.1 \mathrm{mg} / \mathrm{ml}\right.$ for HeLa cells). ${ }^{111}$

The antimicrobial activity of NDI-peptide conjugates depends primarily on the value of the positive charge of the molecule. So, the best antimicrobial activity against $E$. coli and B. subtilus was shown by compounds containing one unit of NDI and at least seven lysine fragments. In addition, the investigated derivatives of NDI are inactive against mammalian cell lines, which makes them promising antimicrobial agents. The results of the study showed that the combination of a positive charge with aromatic and/or hydrophobic elements can be a promising approach to the synthesis of new antimicrobial agents. ${ }^{12}$

Noncovalent binding with nucleic acids is characteristic of all representatives of the diazapyrene group. This is primarily due to the peculiarities of the geometry of the pyrene ring, as well as the high $\pi$-acidity of the aromatic system. Substituents in the diazapyrene ring have a significant effect on the binding selectivity and stability of the complex due to electrostatic and steric interactions with the DNA chain. In addition, some representatives of 

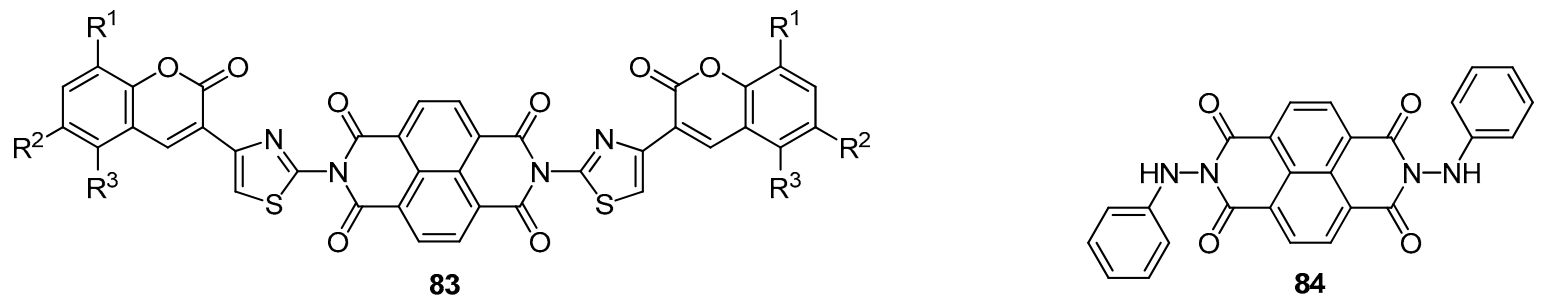

$\mathrm{R}^{1}=\mathrm{H}, \mathrm{Cl}, \mathrm{Br}$, OMe; $\mathrm{R}^{2}=\mathrm{H}, \mathrm{Cl}, \mathrm{Br} ; \mathrm{R}^{3}=\mathrm{H} ; \mathrm{R}^{2}, \mathrm{R}^{3}=\mathrm{CHCH}_{2} \mathrm{CH}_{2} \mathrm{CH}$

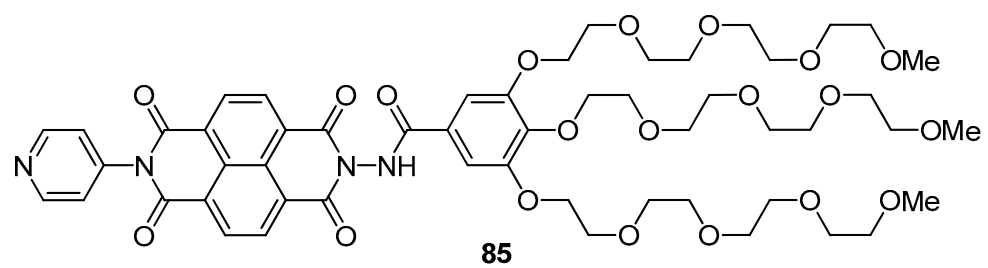

Figure 23. NDI-based compounds $\mathbf{8 3 - 8 5}$ with antibacterial properties.

diazapyrenes are able to photosensitize oxygen and introduce breaks in the DNA chain in the presence of light.

The biological activity of diazapyrene derivatives is determined mainly by their interaction with nucleic acids. Binding to DNA disrupts the functioning of enzymes such as DNA polymerase, telomerase, and topoisomerase, and stabilization of G4 in the promoter regions of genes suppresses their expression. Considering that in many oncogenes G4 are located in the promoter region, many G4 ligands exhibit antitumor activity. However, a clear correlation between antitumor activity and the strength of binding to quadruplex DNA was not found. In addition, the ability to introduce breaks in the DNA chain is an important factor determining the biological effect of diazapyrenes derivatives. The cleavage of the nucleotide chain can be both a consequence of direct photooxidation and the result of photosensitization of molecular $\mathrm{O}_{2}$.

Additionally, the mechanism of the expression of the biological activity of diazapyrene derivatives may include action on lipid membranes. Thus, $N, N^{\prime}$-dimethyl-2,7-diazapyrenium chloride has a destabilizing effect on the lipid bilayer. The mechanism of action of $N, N^{\prime}$-dimethyl-2,7-diazapyrenium, apparently, differs from the mechanism of action of classical destabilizing agents, such as nonionic surfactants. Modeling of molecular dynamics shows that the destabilization of the liposome membrane with $N, N^{\prime}$-dimethyl-2,7-diazapyrenium chloride is due to its ability to surround itself with $\mathrm{H}_{2} \mathrm{O}$ molecules even in highly hydrophobic media, such as the liposome bilayer, which, apparently, promotes the formation of transitional pores in the lipid bilayer. ${ }^{113}$ Oligo( $p$-phenylene)naphthalene diimide facilitates the transport of anions through the lipid bilayer with a rare VI halogen selectivity $\left(\mathrm{Cl}^{-}>\mathrm{F}^{-}>\mathrm{Br}^{-}>\mathrm{I}^{-}\right) .{ }^{114}$ Transmembrane transition of an ion occurs via the ion-slip mechanism without the need for pore formation in the classical sense. ${ }^{115}$ It has been shown that compounds that disrupt transmembrane transport of chloride ions cause cell death by stimulating caspase-mediated apoptosis. ${ }^{116}$
The spectrum of biological activity and the mechanism of action of NDIs is determined mainly by the structure of substituents in the diazapyrene ring. The complexity of the functionalization of diazapyrenes is the main limiting factor in obtaining a large number of compounds for screening and in the rational modification of the structure. The comprehensive study of the biological activity of NDIs, unlike other diazapyrenes, is largely due to the simplicity of synthesis and the presence of a large number of methods for their functionalization. ${ }^{117}$ Hybrid compounds containing NDI and pharmacophore groups of compounds with a studied biological effect, such as sulforaphane, ${ }^{101}$ scriptaid, ${ }^{103}$ and amonafide, ${ }^{118}$ have a great potential. Currently, a number of 1,8-naphthalenimide derivatives have shown significant biological activity, ${ }^{119}$ certain 1,8-naphthalenimides are in the process of undergoing clinical trials. Taking into account that the biological activity of naphthalene diimide analogs of 1,8-naphthalenimide was in some cases higher than that of the original compounds, ${ }^{96,103,118}$ and their toxicity was less pronounced, ${ }^{118}$ we can suggest the prospect of finding effective and safe biologically active compounds among them.

The combination of high biological activity, DNA binding selectivity, and multifactorial action makes diazapyrene derivatives a promising class for the development of chemotherapeutic agents and dictates the need for a comprehensive study of the mechanism of their biological activity.

\section{References}

1. (a) Bolhuis, A.; Aldrich-Wright; J. R. Bioorg. Chem. 2014, 55, 51. (b) Ali, A.; Bhattacharya, S. Bioorg. Med. Chem. 2014, 22, 4506. (c) Nekkanti, S.; Tokala, R.; Shankaraiah, N. Curr. Med. Chem. 2017, 24, 2887.

2. Gibson, D. Pharmacogenomics J. 2002, 2, 275.

3. (a) Balasubramanian, S.; Hurley, L. H.; Neidle, S. Nat. Rev. Drug Discov. 2011, 10, 261. (b) Hansel-Hertsch, R.; Beraldi, D.; Lensing, S. V.; Marsico, G.; Zyner, K.; Parry, A.; Di Antonio, M.; 
Pike, J.; Kimura, H.; Narita, M.; Tannahill, D.; Balasubramanian, S. Nat. Genet. 2016, 48, 1267. (c) Neidle, S. Nat. Rev. Chem. 2017, 1, 0041. (d) Paulo, A.; Castillo, C. C.; Neidle, S. In Comprehensive Medicinal Chemistry III; Chackalamannil, S.; Rotella, D.; Ward, S. E., Eds.; Elsevier: New York, 2017, p. 314.

4. Lipps, H. J.; Rhodes, D. Trends Cell Biol. 2009, 19, 414.

5. (a) Konig, S. L. B.; Huppert, J. L.; Sigel, R. K. O.; Evans, A. C. Nucleic Acids Res. 2013, 41, 7453. (b) Rhodes, D.; Lipps, H. J. Nucleic Acids Res. 2015, 43, 8627.

6. Holder, I. T.; Hartig, J. S. Chem. Biol. 2014, 21, 1511.

7. Zhou, B.; Liu, C.; Geng, Y.; Zhu, G. Sci. Rep. 2015, 5, 16673.

8. Maizels, N. EMBO Rep. 2015, 16, 910.

9. Metifiot, M.; Amrane, S.; Litvak, S.; Andreola, M.-L. Nucleic Acids Res. 2014, 42, 12352.

10. (a) Perrone, R; Nadai, M.; Frasson, I.; Poe, J. A.; Butovskaya, E.; Smithgall, T. E.; Palumbo, M.; Palù, G.; Richter, S. N. J. Med. Chem. 2013, 56, 6521. (b) Perrone, R.; Nadai, M.; Poe, J. A.; Frasson, I.; Palumbo, M.; Palù, G.; Smithgall, T. E.; Richter, S. N. PloS One 2013, 8, e73121. (c) Tosoni, E.; Frasson, I.; Scalabrin, M.; Perrone, R.; Butovskaya, E.; Nadai, M.; Palù, G.; Fabris, D.; Richter, S. N. Nucleic Acids Res. 2015, 43, 8884. (d) Amrane, S.; Kerkour, A.; Bedrat, A.; Vialet, B.; Andreola, M.-L.; Mergny, J.-L. J. Am. Chem. Soc. 2014, 136, 5249. (e) Piekna-Przybylska, D.; Sullivan, M. A.; Sharma, G.; Bambara, R. A. Biochemistry 2014, 53, 2581.

11. (a) Perrone, R.; Butovskaya, E.; Daelemans, D.; Palù, G.; Pannecouque, C.; Richter, S. N. J Antimicrob. Chemother. 2014, 69, 3248. (b) Perrone, R.; Doria, F.; Butovskaya, E.; Frasson, I.; Botti, S.; Scalabrin, M.; Lago, S.; Grande, V.; Nadai, M.; Freccero, M.; Richter, S. N. J. Med. Chem. 2015, $58,9639$.

12. (a) Artusi, S.; Nadai, M.; Perrone, R.; Biasolo, M. A.; Palù, G.; Flamand, L.; Calistri, A.; Richter, S. N. Antiviral Res. 2015, 118, 123. (b) Artusi, S.; Perrone, R.; Lago, S.; Raffa, P.; Di Iorio, E.; Palù, G.; Richter, S. N. Nucleic Acids Res. 2016, 44, 10343. (c) Murat, P.; Zhong, J.; Lekieffre, L.; Cowieson, N. P.; Clancy, J. L.; Preiss, T.; Balasubramanian, S.; Khanna, R.; Tellam, J. Nat. Chem. Biol. 2014, 10, 358. (d) Norseen, J.; Johnson, F. B.; Lieberman, P. M. J. Virol. 2009, 83, 10336.

13. (a) Tan, J.; Vonrhein, C.; Smart, O. S.; Bricogne, G.; Bollati, M.; Kusov, Y.; Hansen, G.; Mesters, J. R.; Schmidt, C. L.; Hilgenfeld, R. PLoS Pathog. 2009, 5, e1000428. (b) Tluckova, K.; Marušič, M.; Tóthová, P.; Bauer, L.; Šket, P.; Plavec, J.; Viglasky, V. Biochemistry 2013, 52, 7207.

14. (a) Fleming, A. M.; Ding, Y.; Alenko, A.; Burrows, C. J. ACS Infect. Dis. 2016, 2, 674. (b) Wang, S.-R.; Min, Y.-Q.; Wang, J.-Q.; Liu, C.-X.; Fu, B.-S.; Wu, F.; Wu, L.-Y.; Qiao, Z.-X.; Song, Y.-Y.; Xu, G.-H.; Wu, Z.-G.; Huang, G.; Peng, N.-F.; Huang, R.; Mao, W.-X.; Peng, S.; Chen, Y.-Q.; Zhu, Y.; Tian, T.; Zhang, X.-L.; Zhou, X. Sci. Adv. 2016, 2, e1501535/1. (c) Wang, S.-R.; Zhang, Q.-Y.; Wang, J.-Q.; Ge, X.-Y.; Song, Y.-Y.; Wang, Y.-F.; Li, X.-D.; Fu, B.-S.; Xu, G.-H.; Shu, B.; Gong, P.; Zhang, B.; Tian, T.; Zhou, X. Cell Chem. Biol. 2016, 23, 1113.

15. (a) Endoh, T.; Kawasaki, Y.; Sugimoto, N. Angew. Chem., Int. Ed. 2013, 52, 5522. (b) Rawal, P.; Kummarasetti, V. B. R.; Ravindran, J.; Kumar, N.; Halder, K.; Sharma, R.; Mukerji, M.; Das, S. K.; Chowdhury, S. Genome Res. 2006, 16, 644.
16. (a) Beaume, N.; Pathak, R.; Yadav, V. K.; Kota, S.; Misra, H. S.; Gautam, H. K.; Chowdhury, S. Nucleic Acids Res. 2013, 41, 76. (b) Kota, S.; Dhamodharan, V.; Pradeepkumar, P. I.; Misra, H. S. Appl. Microbiol. Biotechnol. 2015, 99, 9761. (c) Kota, S.; Misra, H. S. J. Biosci. 2015, 40, 833.

17. Rehm, C.; Wurmthaler, L. A.; Li, Y.; Frickey, T.; Hartig, J. S. PloS One 2015, 10, e0144275/1.

18. (a) Ehrat, E. A.; Johnson, B. R.; Williams, J. D.; Borchert, G. M.; Larson, E. D. BMC Mol. Biol. 2012, 13, 23. (b) Kang, S.-G.; Henderson, E. Mol. Cells. 2002, 14, 404. (c) Liu, N.-N.; Duan, X.-L.; Ai, X.; Yang, Y.-T.; Li, M.; Dou, S.-X.; Rety, S.; Deprez, E.; Xi, X.-G. Nucleic Acids Res. 2015, 43, 8942. (d) McGlynn, P.; Lloyd, R. G. Nucleic Acids Res. 1999, 27, 3049. (e) van Leeuwen, H. C.; Bakker, D.; Steindel, P.; Kuijper, E. J.; Corver, J. Nucleic Acids Res. 2013, 41, 2382. (f) Wu, X.; Maizels, N. Nucleic Acids Res. 2001, 29, 1765.

19. (a) Cahoon, L. A.; Manthei, K. A.; Rotman, E.; Keck, J. L.; Seifert, H. S. J. Bacteriol. 2013, 195, 2255. (b) Cahoon, L. A.; Seifert, H. S. Science 2009, 325, 764. (c) Harris, L. M.; Merrick, C. J. PLoS Pathog. 2015, 11, e1004562/1. (d) Kuryavyi, V.; Cahoon, L. A.; Seifert, H. S.; Patel, D. J. Structure 2012, 20, 2090.

20. Cohen, S. M.; Lippard, S. J. Prog. Nucleic Acid Res. Mol. Biol. 2001, 67, 93.

21. Moroshkina, E. B. Vestn. SPbSU, Ser. 4: Fizika. Khimiya 2011, 4, 114.

22. Lerman, L. S. J. Mol. Biol. 1961, 3, 18.

23. (a) Pommier, Y. Chem. Rev. 2009, 109, 2894. (b) Pommier, Y. Nat. Rev. Cancer 2006, 6, 789.

24. McClendon, A. K.; Osheroff, N. Mutat. Res. 2007, 623, 83.

25. Drlica, K.; Zhao, X. Microbiol. Mol. Biol. Rev. 1997, 61, 377.

26. Palumbo, M.; Gatto, B.; Moro, S.; Sissi, C.; Zagotto, G. Biochim. Biophys. Acta 2002, 1587, 145.

27. Dezhenkova, L. G.; Tsvetkov, V. B.; Shtil, A. A. Russ. Chem. Rev. 2014, 83, 82. [Usp. Khim. 2014, 83, 82.]

28. Balzani, V.; Credi, A.; Langford, S. J.; Raymo, F. M.; Stoddart, J. F.; Venturi, M. J. Am. Chem. Soc. 2000, 122, 3542.

29. Lilienthal, N. D.; Alsafar, H.; Conerty, J.; Fernandez, R.; Kong, C.; Smith, D. K. Anal. Chem. 2003, 75, 3322.

30. Ashton, P. R.; Boyd, S. E.; Brindle, A.; Langford, S. J.; Menzer, S.; Pérez-García, L.; Preece, J. A.; Raymo, M.; Spencer, N.; Frasser Stoddart, J.; White, A. J. P.; Williams, D. J. New J. Chem. 1999, 23, 587.

31. (a) Jazwinski, J.; Blacker, A. J.; Lehn, J.-M.; Cesario, M.; Guilhem, J.; Pascard, C. Tetrahedron Lett. 1987, 28, 6057. (b) Molloy, J. K.; Bergamini, G.; Baroncini, M.; Hahn, U.; Ceroni, P. New J. Chem. 2018, 42, 16193.

32. (a) Stang, P. J.; Olenyuk, B.; Fan, J.; Arif, A. M. Organometallics 1996, 15, 904. (b) Stang, P. J.; Cao, D. H.; Saito, S.; Arif, A. M. J. Am. Chem. Soc. 1995, 117, 6273.

33. (a) Borovlev, I. V.; Demidov, O. P. Chem. Heterocycl. Compd. 2003, 39, 1417. [Khim. Geterotsikl. Soedin. 2003, 1612.] (b) Borovlev, I. V.; Demidov, O. P. Chem. Heterocycl. Compd. 2008, 44, 1311. [Khim. Geterotsikl. Soedin. 2008, 1613.]

34. (a) Calcul, L.; Longeon, A.; Al-Mourabit, A.; Guyot, M.; Bourguet-Kondracki, M.-L. Tetrahedron 2003, 59, 6539. (b) Pham, C.-D.; Hartmann, R.; Muller, W. E. G.; de Voogd, N.; Lai, D.; Proksch, P. J. Nat. Prod. 2013, 76, 103. (c) Yu, H.-B.; 
Yang, F.; Sun, F.; Li, J.; Jiao, W.-H.; Gan, J.-H.; Hu, W.-Z.; Lin, H.-W. Mar. Drugs 2014, 12, 6003.

35. (a) Gul, W.; Hammond, N. L.; Yousaf, M.; Bowling, J. J.; Schinazi, R. F.; Wirtz, S. S.; Garcia de Castro, A.; Cuevas, C.; Hamann, M. T. Bioorg. Med. Chem. 2006, 14, 8495. (b) Larghi, E. L.; Bohn, M. L.; Kaufman, T. S. Tetrahedron 2009, 65, 4257. (c) Arai, M.; Han, C.; Yamano, Y.; Setiawan, A.; Kobayashi, M. J. Nat. Med. 2014, 68, 372. (d) Sa'adah, N. N.; Nurhayati, A. P. D.; Shovitri, M. J. Technol. Sci. 2016, 27. DOI: 10.12962/j20882033.v27i3.1183.

36. Becker, H.-C.; Norden, B. J. Am. Chem. Soc. 1997, 119, 5798.

37. Blacker, A. J.; Jazwinski, J.; Lehn, J.-M.; Wilhelm, F. X. J. Chem. Soc., Chem. Commun. 1986, 1035.

38. Ikeda, H; Fuji, K.; Tanaka, K. Bioorg. Med. Chem. Lett. 1996, $6,101$.

39. Ikeda, H.; Fuji, K.; Tanaka, K.; Iso, Y.; Yoneda, F. Chem. Pharm. Bull. 1999, 47, 1455.

40. (a) Blacker, A. J.; Jazwinski, J.; Lehn, J.-M. Helv. Chim. Acta 1987, 70, 1. (b) Saito, I.; Takayama, M.; Matsuura, T. Tetrahedron Lett. 1989, 30, 2237.

41. Hünig, S.; Groß, J. Tetrahedron Lett. 1968, 9, 2599.

42. (a) Brun, A. M.; Harriman, A. J. Am. Chem. Soc. 1991, 113, 8153. (b) Coudret, C.; Harriman, A. J. Chem. Soc., Chem. Commun. 1992, 1755.

43. Rogers, J. E.; Weiss, S. J.; Kelly, L. A. J. Am. Chem. Soc. 2000, 122, 427 .

44. Kawai, K.; Osakada, Y.; Fujitsuka, M.; Majima, T. J. Phys. Chem. B 2007, 111, 2322.

45. Vicic, D. A.; Odom, D. T.; Nunez, M. E.; Gianolio, D. A.; McLaughlin, L. W.; Barton, J. K. J. Am. Chem. Soc. 2000, $122,8603$.

46. Piantanida, I.; Tomišić, V.; Žinić, M. J. Chem. Soc., Perkin Trans. 2 2000, 375.

47. Piantanida, I.; Palm, B. S.; Žinić, M.; Schneider, H.-J. J. Chem. Soc., Perkin Trans. 2 2001, 1808.

48. Palm, B. S.; Piantanida, I.; Žinić, M.; Schneider, H.-J. J. Chem. Soc., Perkin Trans. 2 2000, 385.

49. Piantanida, I.; Žinić, M.; Marczi, S.; Glavaš-Obrovac, L. J. Phys. Org. Chem. 2007, 20, 285.

50. Long, E. C.; Claussen, C. A. In Small Molecule DNA and RNA Binders: From Synthesis to Nucleic Acid Complexes; Demeunynck, M.; Bailly, C.; Wilson W. D., Eds; WileyVCH: Weinheim, 2002, p. 88.

51. Tanious, F. A.; Yen, S.-F.; Wilson, W. D. Biochemistry 1991, 30, 1813.

52. (a) Czerwinska, I.; Sato, S.; Juskowiak, B.; Takenaka, S. Bioorg. Med. Chem. 2014, 22, 2593. (b) Esaki, Y.; Islam, Md. M.; Fujii, S.; Sato, S.; Takenaka, S. Chem. Commun. 2014, 50, 5967. (c) Marchetti, C.; Minarini, A.; Tumiatti, V.; Moraca, F.; Parrotta, L.; Alcaro, S.; Rigo, R.; Sissi, C.; Gunaratnam, M.; Ohnmacht, S. A.; Neidle, S.; Milelli, A. Bioorg. Med. Chem. 2015, 23, 3819. (d) Islam, Md. M.; Sato, S.; Shinozaki, S.; Takenaka, S. Bioorg. Med. Chem. Lett. 2017, 27, 329. (e) Vasimalla, S.; Sato, S.; Takenaka, F.; Kurose, Y.; Takenaka, S. Bioorg. Med. Chem. 2017, 25, 6404.

53. (a) Islam, Md. M.; Fujii, S.; Sato, S.; Okauchi, T.; Takenaka, S. Bioorg. Med. Chem. 2015, 23, 4769. (b) Islam, Md. M.; Fujii, S.; Sato, S.; Okauchi, T.; Takenaka, S. Molecules 2015, 20, 10963.
54. McKnight, R. E.; Reisenauer, E.; Pintado, M. V.; Polasani, S. R.; Dixon, D. W. Bioorg. Med. Chem. Lett. 2011, 21, 4288.

55. Suseela, Y. V.; Das, S.; Pati, S. K.; Govindaraju, T. ChemBioChem 2016, 17, 2162.

56. Cuenca, F.; Greciano, O.; Gunaratnam, M.; Haider, S.; Munnur, D.; Nanjunda, R.; Wilson, W. D.; Neidle, S. Bioorg. Med. Chem. Lett. 2008, 18, 1668.

57. (a) Collie, G. W.; Promontorio, R.; Hampel, S. M.; Micco, M.; Neidle, S.; Parkinson, G. N. J. Am. Chem. Soc. 2012, 134, 2723. (b) Spinello, A.; Barone, G.; Grunenberg, J. Phys. Chem. Chem. Phys. 2016, 18, 2871.

58. Nadai, M.; Doria, F.; Scalabrin, M.; Pirota, V.; Grande, V.; Bergamaschi, G.; Amendola, V.; Winnerdy, F. R.; Phan, A. T.; Richter, S. N.; Freccero, M. J. Am. Chem. Soc. 2018, 140, 14528.

59. Yang, Q.; Xu, J.; Sun, Y.; Li, Z.; Li, Y.; Qian, X. Bioorg. Med. Chem. Lett. 2006, 16, 803.

60. Doria, F.; Manet, I.; Grande, V.; Monti, S.; Freccero, M. J. Org. Chem. 2013, 78, 8065.

61. Matsugo, S.; Kawanishi, S.; Yamamoto, K.; Sugiyama, H.; Matsuura, T.; Saito, I. Angew. Chem., Int. Ed. Engl. 1991, 30, 1351.

62. Terenzi, A.; Ducani, C.; Blanco, V.; Zerzankova, L.; Westendorf, A. F.; Peinador, C.; Quintela, J. M.; Bednarski, P. J.; Barone, G.; Hannon, M. J. Chem.-Eur. J. 2012, 18, 10983.

63. Czerwinska, I.; Sato, S.; Takenaka, S. Bioorg. Med. Chem. 2012, 20, 6416.

64. Holman, G. G.; Zewail-Foote, M.; Smith, A. R.; Johnson, K. A.; Iverson, B. L. Nat. Chem. 2011, 3, 875.

65. Lee, J.; Guelev, V.; Sorey, S.; Hoffman, D. W.; Iverson, B. L. J. Am. Chem. Soc. 2004, 126, 14036.

66. Smith, A. R.; Ikkanda, B. A.; Holman, G. G.; Iverson, B. L. Biochemistry 2012, 51, 4445.

67. Okamoto, A.; Nakamura, T.; Yoshida, K.; Nakatani, K.; Saito, I. Org. Lett. 2000, $2,3249$.

68. Tansil, N. C.; Xie, F.; Xie, H.; Gao, Z. Chem. Commun. 2005, 1064.

69. (a) Takenaka, H.; Sato, S.; Takenaka, S. Electroanalysis 2013, 25, 1827. (b) Takenaka, S.; Yamashita, K.; Takagi, M.; Uto, Y.; Kondo, H. Anal. Chem. 2000, 72, 1334. (c) Takenaka, S.; Uto, Y.; Saita, H.; Yokoyama, M.; Kondo, H.; Wilson, W. D. Chem. Commun. 1998, 1111. (d) Sato, S.; Yamamura, K.; Takenaka, S. Electroanalysis 2013, 25, 1831.

70. Sato, S.; Fujii, S.; Yamashita, K.; Takagi, M.; Kondo, H.; Takenaka, S. J. Organomet. Chem. 2001, 637-639, 476.

71. Sato, S.; Kondo, H.; Nojima, T.; Takenaka, S. Anal. Chem. 2005, 77, 7304.

72. Yamashita, K.; Takagi, A.; Takagi, M.; Kondo, H.; Ikeda, Y.; Takenaka, S. Bioconjugate Chem. 2002, 13, 1193.

73. Gaiji, H.; Jolly, P.; Ustuner, S.; Goggins, S.; Abderrabba, M.; Frost, C. G.; Estrela, P. Electroanalysis 2017, 29, 917.

74. (a) Steiner-Biocić, I.; Glavaš-Obrovac, Lj.; Karner, I.; Piantanida, I.; Žinić, M.; Pavelić, K.; Pavelić, J. Anticancer Res. 1996, 16, 3705. (b) Roknić, S.; Glavaš-Obrovac, Lj.; Karner, I.; Piantanida, I.; Žinić, M.; Pavelić, K. Chemotherapy 2000, 46, 143.

75. Yu, D.-H.; MacDonald, J.; Josephs, S.; Liu, Q.; Nguy, V.; Tor, Y.; Wong-Staal, F.; Li, Q.-X. Invest. New Drugs 2006, 24, 489.

76. Marczi, S.; Glavaš-Obrovac, Lj.; Belovari, T.; Stojković, R.; Ivanković, S.; Šerić, V.; Piantanida, I.; Žinić, M. Cancer Chemother. Pharmacol. 2008, 62, 595. 
77. Marczi, S.; Glavaš-Obrova, Lj.; Karner, I. Chemotherapy 2005, 51, 217.

78. Cogoi, S.; Ferino, A.; Miglietta, G.; Pedersen, E. B.; Xodo, L. E. Nucleic Acids Res. 2018, 46, 661.

79. Pennarun, G.; Granotier, C.; Gauthier, L. R.; Gomez, D.; Hoffschir, F.; Mandine, E.; Riou, J.-F.; Mergny, J.-L.; Mailliet, P.; Boussin, F. D. Oncogene 2005, 24, 2917.

80. Street, S. T. G.; Chin, D. N.; Hollingworth, G. J.; Berry, M.; Morales, J. C.; Galan, M. C. Chem.-Eur. J. 2017, 23, 6953.

81. Salvati, E.; Doria, F.; Manoli, F.; D'Angelo, C.; Biroccio, A.; Freccero, M.; Manet, I. Org. Biomol. Chem. 2016, 14, 7238.

82. Milelli, A.; Marchetti, C.; Greco, M. L.; Moraca, F.; Costa, G.; Turrini, E.; Catanzaro, E.; Betari, N.; Calcabrini, C.; Sissi, C.; Alcaro, S.; Fimognari, C.; Tumiatti, V.; Minarini, A. Eur. J. Med. Chem. 2017, 128, 107.

83. Hampel, S. M.; Sidibe, A.; Gunaratnam, M.; Riou, J.-F.; Neidle, S. Bioorg. Med. Chem. Lett. 2010, 20, 6459.

84. Gunaratnam, M.; de la Fuente, M.; Hampel, S. M.; Todd, A. K.; Reszka, A. P.; Schätzlein, A.; Neidle, S. Bioorg. Med. Chem. 2011, 19, 7151.

85. Hampel, S. M.; Pepe, A.; Greulich-Bode, K. M.; Malhotra, S. V.; Reszka, A. P.; Veith, S.; Boukamp, P.; Neidle, S. Mol. Pharmacol. 2013, 83, 470.

86. Rasadean, D. M.; Sheng, B.; Dash, J.; Pantos, G. D. Chem.Eur. J. 2017, 23, 8491.

87. Micco, M.; Collie, G. W.; Dale, A. G.; Ohnmacht, S. A.; Pazitna, I.; Gunaratnam, M.; Reszka, A. P.; Neidle, S. J. Med. Chem. 2013, 56, 2959.

88. Ohnmacht, S. A.; Marchetti, C.; Gunaratnam, M.; Besser, R. J.; Haider, S. M.; Di Vita, G.; Neidle, S.; Lowe, H. L.; MellinasGomez, M.; Diocou, S.; Robson, M.; Pedley, R. B.; Hartley, J. A.; Šponer, J.; Islam, B. Sci. Rep. 2015, 5, 11385.

89. Mpima, S.; Ohnmacht, S. A.; Barletta, M.; Husby, J.; Pett, L. C.; Gunaratnam, M.; Hilton, S. T.; Neidle, S. Bioorg. Med. Chem. 2013, 21, 6162.

90. Marchetti, C.; Zyner, K. G.; Ohnmacht, S. A.; Robson, M.; Haider, S. M.; Morton, J. P.; Marsico, G.; Vo, T.; LaughlinToth, S.; Ahmed, A. A.; Di Vita, G.; Pazitna, I.; Gunaratnam, M.; Besser, R. J.; Andrade, A. C. G.; Diocou, S.; Pike, J. A.; Tannahill, D.; Pedley, R. B.; Evans, T. R. J.; Wilson, W. D; Balasubramanian, S.; Neidle, S. J. Med. Chem. 2018, 61, 2500.

91. Gunaratnam, M.; Swank, S.; Haider, S. M.; Galesa, K.; Reszka, A. P.; Beltran, M.; Cuenca, F.; Fletcher, J. A.; Neidle, S. J. Med. Chem. 2009, 52, 3774.

92. Gunaratnam, M.; Collie, G. W.; Reszka, A. P.; Todd, A. K.; Parkinson, G. N.; Neidle, S. Bioorg. Med. Chem. 2018, 26, 2958.

93. Kamal, A.; Adil, S. F.; Tamboli, J. R.; Siddardha, B., Murthy, U. S. N. Lett. Drug Des. Discovery 2009, 6, 201.

94. Sur, S.; Tiwari, V.; Sinha, D.; Kamran, M. Z.; Dubey, K. D.; Suresh Kumar, G.; Tandon, V. ACS Omega 2017, 2, 966.

95. Suseela, Y. V.; Das, S.; Pati, S. K.; Govindaraju, T. ChemBioChem 2016, 17, 2162.

96. Tumiatti, V.; Milelli, A.; Minarini, A.; Micco, M.; Gasperi Campani, A.; Roncuzzi, L.; Baiocchi, D.; Marinello, J.; Capranico, G.; Zini, M.; Stefanelli, C.; Melchiorre, C. J. Med. Chem. 2009, 52, 7873.

97. Di Antonio, M.; Doria, F.; Richter, S. N.; Bertipaglia, C.; Mella, M.; Sissi, C.; Palumbo, M.; Freccero, M. J. Am. Chem. Soc. 2009, 131, 13132.

98. Doria, F.; Nadai, M.; Folini, M.; Di Antonio, M.; Germani, L.; Percivalle, C.; Sissi, C.; Zaffaroni, N.; Alcaro, S.; Artese, A.; Richter, S. N.; Freccero, M. Org. Biomol. Chem. 2012, 10, 2798.
99. Nadai, M.; Doria, F.; Di Antonio, M.; Sattin, G.; Germani, L.; Percivalle, C.; Palumbo, M.; Richter, S. N.; Freccero, M. Biochimie 2011, 93, 1328.

100. Lopergolo, A.; Tortoreto, M.; Beretta, G. L.; Zuco, V.; Borrello, M. G.; Lanzi, C.; Zaffaroni, N.; Folini, M.; Perrone, R.; Richter, S. N.; Doria, F.; Freccero, M. Oncotarget 2016, 7, 49649.

101. Minarini, A.; Milelli, A.; Tumiatti, V.; Ferruzzi, L.; Marton, M.-R.; Turrini, E.; Hrelia, P.; Fimognari, C. Eur. J. Med. Chem. 2012, 48, 124.

102. Xu, X.; Wang, S.; Chang, Y.; Ge, C.; Li, X.; Feng, Y.; Xie, S.; Wang, C.; Dai, F.; Luo, W. MedChemComm 2018, 9, 1377.

103. Pasini, A.; Marchetti, C.; Sissi, C.; Cortesi, M.; Giordano, E.; Minarini, A.; Milelli, A. ACS Med. Chem. Lett. 2017, 8, 1218.

104. Arévalo-Ruiz, M.; Doria, F.; Belmonte-Reche, E.; De Rache, A.; Campos-Salinas, J.; Lucas, R.; Falomir, E.; Carda, M.; PérezVictoria, J. M.; Mergny, J.-L.; Freccero, M.; Morales, J. C. Chem.-Eur. J. 2017, 23, 2157.

105. Callegaro, S.; Perrone, R.; Scalabrin, M.; Palù, G.; Richter, S. N.; Doria, F. Sci. Rep. 2017, 7, 2341.

106. Perrone, R.; Lavezzo, E.; Riello, E.; Manganelli, R.; Palù, G.; Toppo, S.; Richter, S. N.; Provvedi, R. Sci. Rep. 2017, 7, 5743.

107. Ariyasu, S.; Too, P. C.; Mu, J.; Goh, C. C.; Ding, Y.; Tnay, L. Y.; Yeow, E.; Yang, L.; Ng, L. G.; Xing, B.; Chiba, S.; Chem. Commun. 2016, 4667.

108. Dana, S.; Keshri, S. K.; Shukla, J.; Vikramdeo, K. S.; Mondal, N.; Mukhopadhyay, P.; Dhar, S. K. ACS Omega 2016, $1,318$.

109. (a) Belmonte-Reche, E.; Martínez-García, M.; Guédin, A.; Zuffo, M.; Arévalo-Ruiz, M.; Doria, F.; Campos-Salinas, J.; Maynadier, M.; López-Rubio, J. J.; Freccero, M.; Mergny, J.-L.; Pérez-Victoria, J. M.; Morales, J. C. J. Med. Chem. 2018, 61, 1231. (b) Zuffo, M.; Stucchi, A.; CamposSalinas, J.; Cabello-Donayre, M.; Martínez-García, M.; Belmonte-Reche, E.; Pérez-Victoria, J. M.; Mergny, J. L.; Freccero, M.; Morales, J. C.; Doria, F. Eur. J. Med. Chem. 2019, 163, 54.

110. Gurung, S. K.; Dana, S.; Mandal, K.; Mukhopadhyay, P.; Mondal, N. Chem. Biol. Interact. 2019, 304, 106.

111. Sikder, A.; Sarkar, J.; Sakurai, T.; Seki, S.; Ghosh, S. Nanoscale 2018, 10, 3272.

112. iller, C. T.; Weragoda, R.; Izbicka, E.; Iverson, B. L. Bioorg. Med. Chem. 2001, 9, 2015.

113. Zappacosta, R.; Semeraro, M.; Baroncini, M.; Silvi, S.; Aschi, M.; Credi, A.; Fontana, A. Small 2010, 6, 952.

114. (a) Gorteau, V.; Bollot, G.; Mareda, J.; Perez-Velasco, A.; Matile, S. J. Am. Chem. Soc. 2006, 128, 14788. (b) Gorteau, V.; Bollot, G.; Mareda, J.; Matile, S. Org. Biomol. Chem. 2007, 5, 3000. (c) Gorteau, V.; Julliard, M. D.; Matile, S. Science 2008, 321,37 .

115. (a) Mareda, J.; Matile, S. Chem.-Eur. J. 2009, 15, 28. (b) Dawson, R. E.; Hennig, A.; Weimann, D. P.; Emery, D.; Ravikumar, V.; Montenegro, J.; Takeuchi, T.; Gabutti, S.; Mayor, M.; Mareda, J.; Schalley, C. A.; Matile, S. Nat. Chem. 2010, 2, 533.

116. (a) Saha, T.; Hossain, M. S.; Saha, D.; Lahiri, M.; Talukdar, P. J. Am. Chem. Soc. 2016, 138, 7558. (b) Akhtar, N.; Saha, A.; Kumar, V.; Pradhan, N.; Panda, S.; Morla, S.; Kumar, S.; Manna, D. ACS Appl. Mater. Interfaces 2018, 10, 33803.

117. (a) Bhosale, S. V.; Jani, C. H.; Langford, S. J. Chem. Soc. Rev. 2008, 37, 331. (b) Pan, M.; Lin, X.-M.; Li, G.-B.; $\mathrm{Su}$, C.-Y. Coord. Chem. Rev. 2011, 255, 1921. (c) Suraru, S.-L.; Würthner, F. Angew. Chem., Int. Ed. 
2014, 53, 7428. (d) Kobaisi, M. A.; Bhosale, S. V.; 119. (a) Banerjee, S.; Veale, E. B.; Phelan, C. M.; Murphy, S. A.; Latham, K.; Raynor, A. M.; Bhosale, S. V. Chem. Rev. 2016, 116, 11685. (e) Insuasty, A.; Maniam, S.; Langford, S. Chem.-Eur. J. 2019, 25, 7058.

118. Wang, Y.; Zhang, X.; Zhao, J.; Xie, S.; Wang, C. J. Med. Chem. 2012, 55, 3502 . Tocci, G. M.; Gillespie, L. J.; Frimannsson, D. O.; Kelly, J. M.; Gunnlaugsson, T. Chem. Soc. Rev. 2013, 42, 1601. (b) Kamal, A.; Bolla, N. R.; Srikanth, P. S.; Srivastava, A. K. Expert Opin. Ther. Pat. 2013, 23, 299. (c) Tomczyk, M. D.; Walczak, K. Z. Eur. J. Med. Chem. 2018, 159, 393. 